\title{
Sait Faik Abasıyanık'ın Eserlerinde Çalışma İlişkileri
}

\author{
Kutluğ Kağan KARAHAN *
}

\section{Özet}

Çalışma ilişkileri, çalışmanın insanın hayatında en fazla zaman ve kaynak ayırdığı fenomen olması nedeniyle, günümüzün en önemli araştırma alanlarından biridir. Çalışma ilişkilerinin bugün bulunduğu noktayı anlamak içinse çalışma ilişkileri tarihi araştırmaları kritik bir noktada bulunmaktadır. Türkiye'de çalışma ilişkilerinde bugünkü düzenlemelerin ve işçi-işveren ilişkilerinde gösterilen reflekslerin doğru analiz edilebilmesi için; Türkiye çalışma ilişkilerinde bugüne kadar ortaya çıkmış olan gelişmelerin tarihsel bir perspektife ele alınması ve geçmişten günümüze nelerin miras kaldığının irdelenmesi önemlidir.

Türkiye'de çalışma ilişkileri tarihi araştırmalarında bugüne kadar referans alınan kaynaklar genellikle resmi belgeler olmuştur. Ancak pek çok tarihçi edebi eserlerin yazıldıkları dönemi dolaysız olarak yansıtan bir kaynak olduğunu kabul etmektedir. Bu çalışmada Sait Faik Abasıyanık'ın eserleri incelenerek 2. Dünya Savaşı sırasında ve hemen sonrasında çok partili döneme geçiş zamanında çalışma ilişkilerine dair veriler toplanmaya çalışılmıştır. Sonrasında bu veriler döneme ait çalışmaların sonuçlarıyla karşılaştırılmış ve neredeyse tamamıyla birbirlerini doğruladıkları görülmüştür.

Anahtar Kelimeler: Sait Faik Abasıyanık, Çalışma İlişkileri, Çalışma İlişkileri Tarihi, 2. Dünya Savaşı, Çok Partili Döneme Geçiş

Araş. Gör., Yalova Üniversitesi, İIBF Çalışma Ekonomisi ve Endüstri İlişkileri Bölümü / kkagankarahan@gmail.com

YIL: 5 SAYI: 10 


\title{
Labour Relations In The Works Of Sait Faik Abasıyanık
}

\begin{abstract}
As work being the most time and resource allocated phenomenon in human life, labour relations are one of the most important research areas of our time. To understand where labour relation stands today, history of labour relations researches are essential. For analyzing today's regulations in labour and reflexes in worker-employer relations correctly, it's critical to approach progression in labour relations of the past in Turkey in historical context and examine what has descended.

In the studies on history of Turkish labour relations, official documents are mostly used. But a handful of historians agree that literature is a direct resource which narrates the era they have written. In this work we tried to obtain data on labour relations in Turkey while in World War II era and transition to multi-party system just after the war. Then the obtained data has been compared with the data we have form earlier works and it appears that they verify each other.

Keywords: Sait Faik Abasıyanık, Labour Relations, History of Labour Relations, World War II, Transition to Multi-Party System

\section{Giriş}

Günümüzde çalışma ilişkileri tarihine verilen önem gün geçtikçe artmaktadır. Çalışmanın insan hayatındaki rolü ve belirleyiciliğinin her gün etkili olduğu bir dönemde çalışma ilişkileri tarihine duyulan ilgi de yükselmektedir. Çalışma ilişkileri tarihi üzerine yapılan araştırmalar sayesinde Türkiye'de işçi işveren ilişkileri, işçi hakları, sendikalaşma, ücretler gibi çalışma ekonomisinin olmazsa olmaz alanlarında bugüne nasıl gelindiğini görmek mümkün olmaktadır. Özellikle Türkiye gibi genç olan ancak bir yandan da yüzlerce y1llık bir devletin devamı niteliğinde olan bir ülkede bugünü anlamak için geçmişle olan bağı kurmak ve çalışma ilişkileri tarihinde yaşanan gelişmelerin bağlamını kavramak çok önem arz etmektedir.
\end{abstract}


Tarih araştırmaların resmi belgeler ve sözleşmelerin rolü büyüktür. Ancak pek çok tarihçi edebi eserlerin yazıldıkları dönemin özelliklerini oldukça açık bir şekilde yansıttığını düşünmektedir. Öyküler, romanlar ve şiirler yazarın kendi döneminde yaşananlara dair gözlemlerini kendi akıl süzgeçlerinden geçirip, hayal güçleriyle birleştirerek ortaya koydukları eserlerdir. Satır aralarına bakılıp aranan bilgi çekildiğinde, araştırma konumuz her ne ise dönemle ilgili oldukça ilginç anekdotlara ve saptamalara rastlamak mümkündür. Hayatı gözlemleyerek ortaya konan bir eserde de çalışma hayatına ilişkin nüveler bulmamak neredeyse imkansızdır. Bu nedenle çalışma ilişkileri tarihi üzerine yapılan araştırmalarda belli yazarların eserlerini analize tabi tutmak hem dönemi anlamamıza hem de kendi dönemindeki veya diğer dönemlerde yazmış başka yazarlarla karşılaştırma yapmamıza imkan tanıyacaktır.

İşte bu bağlamda, Sait Faik Abasıyanık'ın eserleri çalışma ilişkileri bakımından irdelenmiş ve özellikle 2. Dünya Savaşı ve hemen ardındaki çok partili döneme geçiş aşamasında, Türkiye çalışma ilişkilerinde yaşanan gelişmelere 1şık tutabilecek parçalar aranmıştır. Bulunan bilgiler ise dönemle ilgili elimizde olan verilerle klyaslanarak, bu verilerle ne kadar uyuştuğu incelenmiştir.

\section{Sait Faik Abasıyanık: Hayatı ve Eserleri}

Sait Faik Abasıyanık ya da Sait Faik (d. 18 Kasım 1906 ya da 22 Kasım1906 ya da 23 Kasım1906, Adapazar1- ö.11 Mayıs 1954, İstanbul) Türk öykü-roman yazarı ve şairdir. Türk hikâyeciliğinin önde gelen yazarlarından sayılan Abasıyanık, çağdaş hikâyeciliğe yaptığı katkılarla Türk edebiyatında bir dönüm noktası sayılmaktadır(Sait Faik Abasıyanık, 1993-1994).

Modern Türk hikâyeciliğinin öncülerinden olan Sait Faik, getirdiği yeniliklerle kendi tarzını kendi oluşturmuş bir yazar olarak gösterilmektedir (Yücel,1954,s.9). Klasik öykü tekniğini yıkarak doğayı ve insanları basit, samimi, hem iyi hem kötü taraflarıyla oldukları gibi fakat şiirsel ve usta bir dille anlattığı kabul edilmektedir (Ediboğlu,1954,s.7).

YIL: 5 SAYI: 10 
Toplumun problemlerine değil bireyin toplum içindeki sorunlarına yönelen yazar, öykülerinde çoğunlukla kendisinden yola çıkıp bireyler hakkında yazarak insan gerçeğini anlamaya çalışmıştır (Howard,2001,s.126). Çoğunlukla şehirli alt sınıfın hayatını yazan Abasıyanık, balıkçı, işsiz, kıraathane sahibi gibi karakterlere değinmektedir. İnsanların yaşama biçimlerini, isteklerini, tasalarını, korkularını ve sevinçlerini irdeleyerek, toplum meselelerinden çok "insanı ele alan sanatçılar" sınıfında yer almaktadır (Ağaoğlu,1954,s.7).

1930'larda başladığı yazı hayatı boyunca "sorumlu avare", "gözlemci balıkçı", "çakırkeyf sirozlu", "küfürbaz şair", "müflis tacir", "züğürt yazar", "hamdolsun diyemeyen rantiye", "anadan doğma çevreci" gibi sıfatlarla anılan Abasıyanık'ın tüm yazdıkları bir şair duyarlılığı içerdiği söylenmektedir (Sait Faik Abasıyanık,1993-1994,s.96). Hikâye, roman, şiir yazan, çeviriler ve röportajlar yapan sanatçı bütün bu türleri kendine özgü tarzı ile kaynaştırmıştır.

Yazarın, anlık heyecanlarını yansitan izlenimci ve fovist ressamların üslubunu anımsatan bir tarzı olduğu söylenmiştir (Sait Faik Abasiyanık,1993-1994,s.97).

Kendi özgün dilini oluştururken André Gide, Comte de Lotréamont, Jean Genet gibi isimlerden etkilenen Abasıyanık, kendisinden sonra gelen Ferit Edgü, Adalet Ağaoğlu, Demir Özlü gibi pek çok yazara da öncülük etmiştir. Ölümünün ardından Burgaz Adası'ndaki evi müzeye dönüştürülen yazar adına her sene öykü ödülü de verilmektedir.

\section{Araştırmanın Amacı ve Metodolojisi}

Araştırmanın amacı; Sait Faik Abasıyanık'ın eserleri temelinde Türkiye'de edebiyat ve çalışma ilişkileri arasındaki bağları, çalışma ilişkilerinin Sait Faik'in eserlerine yansımalarını ortaya çıkarmak ve eğer varsa, Türkiye'deki iş̧̧i edebiyatında Sait Faik Abasıyanık'ın yerini tahlil etmektir. Böylece bugüne kadar Türkiye'de çok az üstünde durulmuş olan edebiyat ve çalışma ilişkilerinin bağlantısı hakkında Sait Faik üzerinden sonuçlara ulaşmak mümkün olacaktır. 
Yukarda belirtilen amaç doğrultusunda hareket edilerek, Sait Faik Abasıyanık'ın Semaver,

Sarnıç, Şahmerdan, Lüzumsuz Adam, Mahalle Kahvesi, Havada Bulut, Kumpanya, Havuz Başı, Son Kuşlar ve Alemdağ 'da Var Bir Yılan kitapları ile Birtakım Insanlar(Medarı Maişet

Motoru) ve Kayıp Aranıyor romanları çalışma ilişkilerine dair içeriklerini tespit amacıyla taranmış; ardından kapsamlı ve detaylı bir incelemeye tutulmuştur. $\mathrm{Bu}$ inceleme sonucunda elde edilmiş veriler "ücretler ve yaşam standardı", "çalışma koşulları" "iş sağlı̆̆ı ve güvenliği ile iş kazaları", "çalışma süreleri”, “çocuk işçiliğgi”, “işsizlik ve istihdam” ve "örgütlenme ve grev" başlıkları altında analiz edilmiştir. Araştırmanın sonunda Sait Faik ve çalışma ilişkileri arasındaki bağlar genel olarak toparlanmıştır. Elbette araştırma boyunca dönemin, özellikle çalışma ilişkileri alanında incelendiği kaynaklara da başvurulmuştur. Böylece daha sağlıklı bir karşılaştırma imkanı sağlanması amaçlanmıştır.

\section{Sait Faik Abasıyanık ve Çalışma İlişkileri}

\section{1. Ücretler ve Yaşam Standardı}

Sait Faik'in eserlerine baktığımızda ücretler konusunda, memurlar ve işçiler arasında net bir ayrım olduğunu görürüz. Eserlerde memurlar nispeten daha çok ücret alan ve daha rahat şartlar altında yaşayan insanlar olarak karşımıza çıkmaktadır. Yazarın eserlerinde kendi gözlemlerini aktardığını düşünüldüğünde ve döneme ait ücret verileri incelendiğinde bu durumun gerçeği yansıttığı söylenebilir. Cumhuriyetin ilk yıllarında bürokratların ayrıcalıklı bir konumda olmaları nedeniyle bölüşümden aldıkları pay daha fazladır (Tataroğlu, 2012, s.228). Yazarın en fazla eser verdiği dönemler savaş yılları olduğundan reel ücretlerde büyük bir düşüş yaşanmıştır. Ancak kamu kesimi ücretlerinde yaşanan düşüş özel kesimdeki kadar yüksek olmamakla birlikte kamu kesiminde lojman, yiyecek, giyecek, yakacak gibi yardımlar ayrıca destek olmaktadır (Makal, 1999, s.431-441). Eserlerde, gerek ücretler gerek yaşam standartları bakımından memur ve işçi arasındaki farklılıklar bu kadar açık olduğundan; incelemeyi de böyle bir ayrım çerçevesinde yapmak doğru olacaktır.

YIL: 5 SAYI: 10 


\subsection{1. İşçilerin Ücretleri ve Yaşam Standartları}

Yazarın eserlerinde ücretlerle ilgili sayısal veriler yaşam standartlarına ilişkin verilere nazaran oldukça az olsa da döneme dair genel bir fikir vermek için yeterli sayıda olduğu söylenebilir. Daha önce de belirtildiği gibi işçilerin ücretleri oldukça düşüktür. İşçilerin çalıştıkları sektöre bağlı olarak, bunun derecesi de değişmektedir. Örneğin "Şahmerdan" hikâyesinde çok ağır şartlarda çalışmalarına rağmen, şahmerdanı işleten işçiler bu işi günlüğü 1 liraya yapmaktadırlar (Abasıyanık, 1940/2008d, s.9). Havuz Başı kitabının "Kumarbaz Hayri Efendi” öyküsünde de kapıcıların ayda 60 lira aldıkları belirtilmektedir (Abasıyanık, 1952/2009b, s.15). "Sur Dışında Hayat" öyküsündeki deri kazıyıcısı ayda 20 lira kazanmaktadır (Abasıyanık, 1952/2009b, s.74). Birtakım İnsanlar romanında Ruhi Kaptan ayda 500 lirayı rahatça harcayabilirken, tekne motorcusu Hikmet haftada 5 lira kazanmaktadır (Abasıyanık, 1944/2008b, s.22). Daha sonra ada bekçiliğine başladığında Hikmet' in aldığı ücret ayda 40 liraya çıkmıştır (Abasıyanık, 1944/2008b, s.117). Yine aynı romanda bir yük motorunda çalışan Mustafa sefer başı 3,5 lira almaktadır (s. 124-125). Romanda, yine aynı bölümde aslında ortalama bir tekne işçisinin sefer başı 10 lira aldığı da belirtilmiştir (s.126). Yine aynı romanda istasyonda valiz taşıyan bir hamalın yük başına 60-70 kuruş kazandığı söylenmektedir (s.132).

Yukarıdaki örneklerde görülebildiği gibi ücretler yaşamı ancak devam ettirebilecek seviyededir. Zaten bu nedenle işçilerin özellikle giyecek ihtiyaçlarının sıklıkla işverenler tarafından karşılandığı görülmektedir. Yazarın işçilerden bahsettiği hemen hemen bütün eserlerinde bunun örneklerine rastlanmaktadır.

Birtakım İnsanlar romanında teknede çalışan Ali Rıza'nın 10 lira karşılı̆̆ında kendisine işkence eden kaptan ve tayfası hakkındaki şikâyetini geri alması, düşük ücretlerin ortaya çıkardığı kaçınılmaz bir maddi sonuç olarak karşımıza çıkmaktadır (Abasıyanık, 1944/2008b, s.34). "Kestaneci Dostum" öyküsünde, hamalla ilgili "Bir evin önünde durdular. Adam ancak o zaman, ne vereceğiz evlat, dedi. Gülümsedi. Boynunu büktü. İki çeyrek aldı. Gene gülümsedi. Yürüdü.” (Abasıyanık, 1950/2009d, s.91) şeklinde aktarılan anekdot, ücretlerin düşüklüğüne rağmen çalışanların 
hizmetlerinin karşılığında para istemekten utanabildiklerini gösteren ilginç bir örnek olarak gözükmektedir.

Eserlerde ücreti nispeten daha iyi olan hatta oldukça yüksek ücretlerin kazanıldığı bazı işlerle de karşılaşılmaktadır, fakat bunların sayısı fazla değildir. Burada kâtipler ön plana çıkmaktadır. Yazarın "Birahanedeki Adam" ve "Bir Ev Sahibi" isimli öykülerinde bahsi geçen kâtipler, sırasıyla ayda 100 lira ve 60 lira kazanmaktadırlar (Abasıyanık, 1948/2009c, s.22 ve Abasıyanık, 1952/2009b, s.32). Bu ücretler, yazarın eserlerinde, o dönemde ortalama bir memurun kazandığı paraya eştir. Bunda da aynı memurlar da olduğu gibi kâtipliğin eğitim isteyen bir meslek olmasını etkisi olduğu söylenebilir. Birtakım İnsanlar romanındaysa bu kez dalgıçlık yüksek kazançlı bir meslek olarak karşımıza çıkmaktadır. Romanda dalgıçların günlüğü 35 liraya çalıştığı söylenmektedir (Abasıyanık, 1944/2008b, s.56 ve s.62) ki bu, o günün şartlarında çok yüksek bir rakamdır. Elbette bunun en büyük sebebinin, dalgıçlığın özel bir uzmanlık ve belli bir fiziki dayanıklılık gerektirmesi olduğu söylenebilir.

Eserlerde fark edilebilecek bir diğer ayrıntı, 2. Dünya Savaşı sırasında seferberlik nedeniyle fiyatların tavan yapmasına rağmen ücretlerin aynı kalmasıdır. Özellikle "Bir Ev Sahibi" adlı hikâyede bu durum "Bizim 60 lira aylıkla 14 lira ev kirası hiç ele geçmemiş gibi oluyor. Hemşire s1kıntıda, ben darda. Zaman geldi, kuru fasulye pişirebilmek için eskiden ağız ağza dolu kileri talan ettik" (Abasıyanık, 1952/2009b, s.33) cümleleriyle açıklanmaktadır. Yine "Beyaz Altın" isimli hikâyede bu durumla ilgili "Bu çok yakın mazide tokları açlar doyurdu ve açlar öldüler. Kimisi vatan, kimisi şeker ve un için ölen bu insanların yaşadığı devirde, bir Eskicizade'nin yazıhanesinde öğle yemeği yemenine kadar mühim bir şey olduğu... Ben sessiz açlardandım. İsyan duymuyordum. Kimseye karşı sesimi yükseltecek kudreti kendimde bulmuyordum. Bütün şehir halkı gibi zaman diyor, harp diyordum. Ama toklar adamakıllı tıkınıyordu. Karnım açtı. Ekmekten sıçankuyruğu çıkmıştı. Midem bozuktu. Öyle olduğu halde kaçak cıgaramla hali unutmaya çalışıyordum. Bu insanlar benden ne istiyorlardı da... midelerinde vesika ekmeğinden başka bir şey olmayan insanlar nasıl zamanı düşünebiliyorlar, sulh, harp diyorlardı? Niçin çocuklarından ve tarlalarından bahsetmiyorlardı?" (Abasıyanık, 1939/2009e,

YIL: 5 SAYI: 10 
s.23-25) ifadeleri yer almaktadır. Bu öyküde aynı zamanda çalışanların hiçbir hak talebinde bulunmaması ve sessiz kalmaları da yazar tarafindan eleştirilmektedir.

Elbette bu düşük ücretler işçilerin kılık kıyafetlerine de yansımıştır. Örneğin "Birtakım İnsanlar” öyküsünde yazarın "Ona benzer adamlar, ötekilerden kolaylıkla ayrılabilirdi. Kış günü bir şehirde insanlar palto, şapla giyer, ayaklarında fotinleri vardır. Bu adamın ne paltosu, ne şapkası ne de ayakkabıları vardı" şeklinde yaptığı açıklama, sokakta bir işçiye bakıldığında onun kılık kıyafetinden işçi olduğunun anlaşıldığını gösteren bir örnektir (Abasıyanık, 1936/2009f, s.69). Yine "Mavnalar" isimli öyküde geçen "Üstünden başından amele olduğu anlaşılan bir adam" betimlemesi buna benzer bir örnektir (Abasıyanık, 1939/2009e, s.35). "Plaj İnsanları" adlı hikâyede bu durum "Fakat sandalcı ve emsalini özlemesi pek ötekilere benzemez. Şimdi aynı güzel şeyleri onlara versek giymeye uzun müddet tereddüt edecekler" cümleleriyle açıklanmıştır (Abasıyanık, 1939/2009e, s.80). "Mürüvvet" isimli öyküde yapılan "Heriflerinin hepsinin üstü çuval bezinden" tanımlaması da zaten işçilerin üstlerine başlarına bir şeyler alacak paraları olmadığını açıkça gözler önüne sermektedir (Abasıyanık, 1948/2009c, s.26). Birtakım İnsanlar romanındaki "Ben artık hamallık balıkçılık yapacak vaziyette değilim... Şu üstüme başıma bak! Bana vız gelir ama senden utanıyorum. "Bak Melek'in babasına!" diyecekler" ve "Fakat o mağrurdur. İnsanın içine ilk defa çıplak bir yeri gözükmeden çıktığı için rahattır. Sakindir. Eh, şimdi artık bir adamdır da: motorcu” cümleleri, işçilerin kendilerinin de bu durumdan yaşadıkları rahatsızlıkları ve toplum karşısında hissettiklerini ifade etmektedir (Abasıanık, 1944/2008b, s.19 ve s.22).

Sait Faik çok fazla olmasa da işçilerin yaşadıkları evler ve mahalleler ile ilgili gözlemlerini de eserlerine aktarmıştır. "Mavnalar" isimli öyküde işçilerin birlikte kaldıkları odayı; simsiyah, karanlık ve karanlık, rutubetli olarak tanımladığı avluya bakan pencereden gün 1şığının zor girdiği bir yer olarak anlatmıştır. Ayrıca işçilerden birinin yorganı dahi yoktur (Abasıyanık, 1939/2009e, s.37). Yine "Mürüvvet" isimli öyküde kolu kesilen işçinin 4 kişiyle aynı odada kaldığından bahsedilmektedir (Abasıyanık, 1948/2009c, s.27). İşçilerin aile kurmadıkları takdirde 
sürekli birlikte kaldıkları, eserlerde sıklıkla görülmektedir. Zaten işçilerin tek başlarına bir oda tutacak maddi durumları olmadığı ortadadır. "Yorgiya'nın Mahallesi” hikâyesinde de muhacirlerin birkaç gün için yapılmış küçük barakalarda kaldıklarına dair gözlemlere yer verilmiştir (Abasıyanık, 1951/2009a, s.53). Fakat bu konuda en ayrıntılı tespitler, yazarın Dolapdere ve Yenişehir'e yaptığı bir geziyi aktardığ 1 "Dolapdere" isimli öyküdür. Bu semtler İstanbul'da işçilerin yoğun olarak ikamet ettikleri semtlerdir. Yazar buraları, "Elmadağı; kulübeler, tahtadan, taştan, sacdan ve mukavvadan kulübeler görürsünüz. Çıplak, çırılçıplak çocuklar görürsünüz. Çıplak, çırılçıplak, aynasız, hasırsız, iskemlesiz kahveler görürsünüz. Mahalle bir bayram yeri gibidir. Öyle kızlar görürsünüz ki içiniz titrer ama burnunuzun alışık olmadığı ağır kokuya çare yoktur. İleride bir fabrika gürül gürül işlemektedir. Mahalle gençlerinin çoğu bu emprime fabrikasına gider. Fabrikanın etrafını bu sefil evler, kaldırımsız, seki sahtiyan, amonyak, insan fabrikasının küsbesi kokulu sokaklar çevirmiştir. Yağmurlar yağmışsa sel önce buraları basar. Yaz geceleri meltem öteki semtleri bir rüya serinliğine boğarken burada yaprak oynamaz" şeklinde anlatmıştır (Abasıyanık, 1954/2008a, s.83-85). Gerçekten bütün bu örnekler işçilerin ne kadar kötü şartlarda yaşadıklarını göstermektedir. O kadar ki işçiler için sabahlar bile işçiler için ayrı bir ızdırap konusu olmaktadır. Yazar "Gaz Sobası" adındaki hikâyede "Fakat ilk güneş tekrar sahici dünyanın firtınaları, buhranları, kıtlıkları, vergileri, azapları, tufanları ve ölümleri ile kendilerini beklediğini delikanlılara söylediği zaman" cümlesiyle, sabah aydınlıkta yaşadıkları mahallelerin görüntüsünün işçilerde uyandırdığı hisleri dile getirmektedir (Abasıyanık, 1939/2009e, s.76).

Yazar eserlerinde işçilerin boş zamanlarında yaptıkları aktivitelere de az da olsa yer vermiştir. "Semaver" isimli öyküde "Karşı kahveye arkadaşlarının yanına koştu. Bir pastra oynadılar.”, Alemdağ'da Var Bir Yılan kitabındaki "Panco'nun Rüyası" öyküsündeki "Akşamüstleri işleri bitirir bitirmez cadde üstünde bir kahveye koşar, kumar oynarım." cümlelerinde aktarıldığ1 üzere işçiler genelde işten çıktıktan sonra vakitlerini kahvede oyun oynayarak geçirmektedirler (Abasıyanık, 1936/2009f, s.10 ve Abasıyanık, 1954/2008a, s.29). Maddi durumları sebebiyle gezmek ya da hobi edinmek gibi firsatları olmayan bu insanların yaşadıkları mahalle-

YIL: 5 SAYI: 10 
lerin kahvelerinden çıkmamaları doğal karşılanabilir. Bu durum yazarın eserlerine Sarnıç kitabının "Mavnalar” isimli öyküsünde geçen "Üsküdar uzaktan bakılacak ve oraya gidilemeyecek kadar uzak, garip bir güzel köy haliyle karanlığın içinden kırmızımsı seyrek elektrikleriyle çoktan uyumuştu." satırlarına da yansımıştır (Abasıyanık, 1939/2009e, s.35). Fakat işçilerin sadece gündüz çalışan akşam da kumar oynayan insanlar olmadıklarını belirtmek gerekir. Örneğin yazarın "Semaver" isimli öyküsünün kahramanı akşam eve geldiğinde kitap okumayı tercih etmektedir (Abasıyanık, 1936/2009f, s.11). Yine Mahalle Kahvesi isimli kitabın "Gramofon ve Yazı Makinesi" isimli öyküsünde işçiler satın aldıkları gramofonun başında müzik dinleyerek eğlenmektedirler (Abasıyanık, 1950/2009d, s.59).

Yazar eserlerinde işçilerin diğer sınıflardan insanlar hakkındaki düşüncelerine de yer vermiştir. Sarnıç isimli kitabın "Beyaz Altın” öyküsünde geçen "Tüccar adam kimsenin kölesi değildir. Hepimiz onu dinliyor hak veriyorduk." sözleri işçilerin zengin olmayı bir özgürleşmek için bir koşul olarak gördüklerini yansıtmaktadır (Abasıyanık, 1939/2009e, s.26). Yine aynı öyküdeki “...firınların önündeki insanlar; otomobildeki toklara, bizim kasabada Eskicizade'ye baktı̆̆ımız gibi bakıyorlardı." satırları işçilerin varlıklı insanlara gıpta ile batkılarına dair bir anekdot olarak karşımıza çıkmaktadır (s.28). Zaten Kayıp Aranıyor isimli romandaki 'Balıkçı Kalafat'la Mimar Mühendis Dağdiken arasında kanun nazarında hiçbir fark yoktur, orası öyle. Ama bu, yalnız yargıcın karşısında böyle. Hayatta ikisini birbirinden ayırt edip konuşmazsan aç kalırsın. Para kimdeyse düdük ondadır." cümleleri işçilerin kendilerini bir çeşit ikinci sınıf insan olarak gördüklerini göstermektedir (Abasıyanık, 1953/2008c, s.11-12). Semaver isimli kitabın "Garson" adlı öyküsünde Ahmet'in daha yüksek bir kazançla ve daha iyi şartlarda garson olarak çalışmak yerine kendi kahvesini işletmek için bin bir zorluğa katlanıyor olması da bunun bir yansıması olsa gerekir (Abasıyanık,1936/2009f, s.63-64).

Eserlerde işçilerin alçak gönüllü ve mütevazı hatta utangaç insanlar olduğu gözlemlenmektedir. Örneğin Sarnıç kitabının "Plaj İnsanları" isimli öyküsünde adanın zenginlerinden birinin kızı bisikletle geçerken işçilerden biri hislerini "Bize, sandalcılara, çapaçullara, kardeşinin bisik- 
letine bindiği zaman... uçup giden kokusunu arzu ile koklamak kalmıştır. Zaman olur ki, bu bile bizim için kâfidir." sözleriyle açıklamaktadır (Abasıyanık, 1939/2009e, s.83). Yine Kumpanya isimli kitaptaki "Kriz" öyküsünde geçen "Tam karşısında ekmekle peynir yiyen genç bir amele var. Yüzü biraz karışık ve mahcup bir çocuk. Bir gazete kâğıdını yere koymuş ve bir ucunu içindeki ekmek ve peyniri kimse görmesin diye kaldırmış.

Kâğıdın içinde küçük lokmalar koparıyor. Büyük parmaklarını arasında bu lokmalar kayboluyor. Ve ağzına gözükmeyen parçalar atıyordu" sözleri işçilerin yemek yerken bile başkalarından utandıklarına dair bir gözlemi aktarmaktadır (Abasıyanık, 1951/2006, s.74). Aynı kitaptaki "Kumpanya" isimli öyküde "Para hiçbir zaman insanı adam etmezdi. İyisi mi, buldu mu, yemeliydi. Yoksa bizim bilemeyeceğimiz bir görüşe, bir ahlaka saplanırdı insan. Bu ahlakta yalnız, o para denilen şeyi her ne pahasına olursa olsun kazanmak vardı. Şeref de oydu. Ahlak da oydu. Namus da oydu." cümlelerinde görülebileceği gibi işçiler zenginlerin hayatlarına özenmelerine rağmen kültürlerinden hiç haz etmemektedirler (s.39).

Elbette yazarın eserlerinde zenginlerin işçiler hakkındaki düşüncelerine de az sayıda da olsa rastlanmaktadır. Havuz Başı isimli kitaptaki "İnsanlar, Türküler, Masallar" adlı hikâyede "Nedense yol amelesinin gözlerinden müteahhitler müteahhidi bir tuhaf oluyordu. Niçin yiyecek gibi bakıyorlardı? Yoksa ona mı öyle geliyordu? Hâlbuki sakalları büyümüş insanlar, günlerce taş kırıp türkü söyleyen, zeytin ekmekle doyan adamlar başka türlü bakmazlardı. Bu bakış, alelade sakalları büyümüş, yorgun insanların bakışı idi. Bu ihtiyar, köse sakallı kendini yorulmadan para kazananlardan saydığı için yorulanların halini bilmiyordu. Yoksa onlar sessiz, sakin, korkak bakışlı insanlardı. Onlar bir gün türkü söyleyerek, sırtlarındaki koyun pöstekilerine doldurulmuş birkaç eşya, çarıklarının tamiri için kendi yaptıkları köseleler, hatta budaktan iğnelerle, kimi bir küçük ne olur ne olmaz altınla yol kenarına çalışmaya gelirlerdi." cümlelerinden anlaşılabileceği gibi yazar sadece işverenlerin düşüncelerini yansıtmamakta bu düşüncelerden duyduğu tiksintiyi de aktarmaktadır (Abasıyanık, 1952/2009b, s.86).

YIL: 5 SAYI: 10 
Son olarak eserlerde dikkat çeken bir başka durum da düşük yaşam standartlarının bozduğu aile ilişkileridir. Örneğin Havuz Başı kitabının "Sur Dışında Hayat" öyküsünde düşük ücretinden dolayı karısının terk ettiği bir deri kazıcısı yer almaktadır (Abasıyanık, 1952/2009b, s.74). Yine aynı kitaptaki "Bir Ev Sahibi”" isimli öyküde ablasıyla yaşayan bir kâtibin harp zamanı ücreti artmadığından girdikleri sıkıntı sonucu ablasıyla kavga edip evden ayrıldığı görülmektedir (s.33-34). Buna benzer bir diğer örnekte de Birtakım Insanlar isimli romanda Ali Rıza Bey, sokakta yaşayan bir çocuğu eve aldığı için karısıyla kavga etmiştir (Abasıyanık, 1944/2008b, s.20).

\subsubsection{Memurların Ücretleri Ve Yaşam Standartları}

Sait Faik'in eserlerinde memurların ücretlerinden de sıklıkla bahsedildiği görülmektedir. Fakat bu kez, belki de memurların ücretlerinin işçilerden daha yüksek olması sebebiyle yazarın ücretleri yansıtma şekli de değişmiş ve genelde işçilerin hayranlıkla ve bazen de şaşkınlıkla karşıladıkları rakamlar olarak karşımıza çıkmaktadır. Memurluk bürokratik bir yapılanmanın içinde yer aldığından, elbette ücretler öykülerde geçen kişiler arasında farklılıklar göstermektedir. Açıkça görülmektedir ki aradaki fark işçilerin arasındaki ücret farkından çok daha fazladır.

Eserlerde ücretlerle ilgili sayısal verilere bakıldığında Sarnıç kitabındaki "Plaj İnsanları" öyküsünde bahsi geçen bir memurun aylık 180 lira aldığı, "Paşazade" isimli öyküde banka memuru olarak yeni işe başlamış Recai'nin ayda 45 lira kazandığı, Birtakım Insanlar romanındaysa Çanakkale'de memurluk yapan birinin ayda 75 lira aldığından bahsedilmektedir (Abasıyanık, 1939/2009e, s.83; 1940/2008d, s.51; 1944/2008b, s.135).

Ücretler arasındaki farkların yüksekliği rahatlıkla görülebilmektedir. Yine işçi ücretlerine nazaran memur ücretlerinin ne kadar yüksek olduğu da sayısal örnekler ile daha dikkat çekici hale gelmiştir. Dikkat çekici bir nokta da yazarın savaşın bitiminden yaklaşık 10 yıl sonra geçen ve son döneminde yazmış olduğu eserlerinde işçilerin ücretlerinde pek bir değiş̧me olmamışken bu dönemde yazılmış olan "Çarşıya İnemem” isimli öykü 
ile Kaylp Aranıyor isimli romanda memur ücretlerinin 300-400-500 lira olduğundan bahsedilmesidir (Abasiyanık, 1954/2008a, s.78; 1953/2008c, s.70). Gerçekten aradan geçen dönemde ortaya çıan fark, özellikle işçi ücretlerindeki artışla karşılaştırıldığında muazzamdır.

Yazarın memur maaşlarını tüccar ve esnafların gelirleriyle karşılaştırdığına da çeşitli öykülerde rastlanılmaktadır. "Beyaz Altın" hikâyesinde geçen "Tüccar adam kimsenin kölesi değildir. Hepimiz onu dinliyor hak veriyorduk. Bu rakıları, bu pirzolaları... belki en büyük memur yiyemiyordu" gözlemi ve "Ben Ne Yapayım" isimli öyküde "Eskiden memur olan bir arkadaşım var. Geçenlerde rastladım. Şık, temiz elbiseler, bilmem nereden alınmış 14,5 liralık bir kravat, 65 liralık pabuç! Yahu, bu ne hal? Dedim. "Memuriyetten ayrıldım, ticaret yapıyorum" şeklinde aktarılan anekdotlar bize memurların kazançlarının tüccarların gelirleriyle kıyaslanamayacağını göstermektedir (Abasıyanık, 1939/2009e, s.26 ve 1948/2009c, s.19). Bahsedilen tüm gelir düzeylerine bakıldığında, ücretli çalş̧anların tüccarlar ve mülk sahiplerine yakın bir düzeyde olasının mümkün olmadığı açıktır.

Sait Faik'in eserlerinde dikkat çeken bir başka husus da memurların halk karşısında takındıkları tutumlardır. Eserlerde bahsi geçen memurlar, işçilerle aralarındaki gelir düzeyi farkını onlara yansıtmaktan çekinmemektedirler. Öykülerde bahsedilen memurların çoğu halkın geri kalanına elitist bir biçimde yaklaşmaktadırlar. Elbette bunda yazarın memurlara karşı olumsuz bakış açısının etkili olma ihtimali varsa da gördüklerini aktaran bir yazar olan Sait Faik'in memurlara olumsuz yaklaşmasına bu tür davranışların yol açması ihtimali daha yüksek görünmektedir. Bu düşüncelerin bir tezahürüne "Plaj İnsanları" öyküsündeki "Telefon şirketi memurunun pipoyu ağzına tıkışından haletiruhiyesini anlayabiliriz... İnsana öyle geliyor ki, fiyakasını tütüne tercih ediyor... cakasızları bakkal çırağını... kendisinden milyon defa aşağı görüyor gibi geliyor" cümlelerinde rastlanılmaktadır (Abasıyanık, 1939/2009e, s.83). Yine bu öyküde bahsedilen bir diğer memuru tanımlarken, yazarın "O galiba ecnebi mektebinde okumuştur. O da memurdur. Şöyle böyle değil, 180 liralık... çalışan kazanan bir insandır, ne denebilir? Fakat ne tuhaf, ne fena bir zihniyeti vardır; tamamen burjuva, biraz da kozmopolit bir terbiyenin insanı insan edeceği-

YIL: 5 SAYI: 10 
ne kanidir" şeklinde yaptığı betimleme, özellikle yüksek seviyede memuriyet hayatını sürdüren insanlarda da bir tür burjuva hayranlığı oluştuğunu göstermektedir (s.83). Ayrıca bu öyküde, iyi bir maaşı olduğu belirtilen telefon şirketi memurunun, çalışma koşulları başlığı altında bahsedilecek olan, memurların sorumluluklarından dolayı insani görevlerini yerine getirememeleri durumundan farklı olarak; sırf üstü başı 1slanmasın diye boğulmakta olan bir kişiye yardım etmemesi (s.85), mertebesi yükseldikçe memurların hayata bakışlarının da değişmeye başladığını göstermektedir. Elbette bu kişisel bir özellikmiş gibi gözükse de memurların içinde bulundukları katı bürokratik yapının, bu karakterin gelişiminde rol oynayıp oynamadığı tartışılmalıdır. Yine Şahmerdan isimli kitabın "Paşazade" isimli öyküsünde geçen "Bakanlara selam vermezdim fakat, iyi delikanlı, sessiz çocuk, iş bulmuş, aferin! Çalışıyor, dediklerini duyardım.” (Abasıyanık, 1940/2008d, s.52) cümlesi, memurların kendilerini halkın diğer kesimlerinden daha yukarıda gördüklerini gösteren bir diğer anekdot olarak karşımıza çıkmaktadır. Kanımızca bu tavrın oluşmasında Cumhuriyetin ilk dönemlerinde devletin halk üzerinde mutlak ve sarsılmaz bir irade kurma çabalarının oldukça etkili olduğu bir düşünülmektedir.

Eserlerde halkın devlet memurlarına bakış açısı da dikkat çekici bir unsurdur. Şahmerdan kitabındaki "Paşazade" isimli öyküde, oğlunun banka memuru olarak işe başladığı gün annesinin oğluna "Artık, dedi, Hüsamettin Paşa'nın gelini değilim, oğlum, banka memuru Recai Bey’in anasıyım" (s.52) demesi ve oğlunun o günü "Bahçeye çıktık. Babamın kolağası olduğu günkü gibi, sanki bütün bahçe, Japon fenerleriyle süslüydü” (s.52) diye anlatması insanların memurluğa gıpta ile baktığını gösteren bir örnektir. Yine, yazarın "Bir Hastalık" isimli öyküsünde yer alan "Bu yakın köylerin insanları kasabalı ile temas etmeyi büyük şeref sayarlar. Hele mesela tahrirat kâtibi, nüfus memuru, belediye reisi, telgraf müdür ile tanışmışlarsa iş tamamdır. Artık köylülükten kurtulmuşlardır. Hiç köyde oturmazlar. Buralarda bir de ortaokul Fransızca öğretmeni ile iki bardak bira içmişlerse köye döndükleri zaman Paris’ten bile söz açabilirler" (Abasıyanık, 1954/2008a, s.87) cümleleri, halkın gözünde bir memurla tanışık olmanın bile bir fark yarattığını gözler önüne sermektedir. Bu başta içi boş bir devlet hayranlığ gibi yorumlanabilirse de bu duruma neden 
olan sebepler olarak memurların toplumda o dönem çok az sayıda olan eğitimli insanlar arasında olmaları ve aldıkları yüksek ücret yanında göreli bir iş güvencesine de sahip olmalarını görmek daha makul olacaktır.

Şahmerdan isimli kitaptaki "Paşazade" isimli öyküde geçen "Son pandantifini sattığı gün, ben de bankadan ilk maaşımı almıştım. Evimiz senelerdir 45 lira görmemişti. “Ayda 45 lira ile Topkapı'da neler yapılmaz?" dedi, anam. "Bahçeyi mi düzeltmeyiz, tavuklar mı almayız, piliç mi çıkartmayız, çamı mı budatmayız, havuzu mu tamir etmeyiz?” (s.51) cümleleri memurların görece daha iyi olan durumlarının bir yansıması olarak karşımıza çıkmaktadır. Fakat yine de alt tabaka memurların yaşam standartları bakımından işçilerden çok da farklı olmadıkları kabul edilmelidir. Bu duruma yazarın Şahmerdan kitabında "Satılık Dünya" hikayesinde değinilmiştir. Bu öyküde hayat şartları nedeniyle çocuğunun ölümüne şahit olan bir memurun yavaş yavaş delirmesi konu edinilmiştir (s.75-78).

Son olarak şunu söylemek gerekir ki yazar için memurlar arasında öğretmenlerin ayrı bir yeri vardır. Sait Faik ne öğretmenler ne de eğitim kurumları hakkında memurlar ve devlet kurumları için duyduğu öfkeyi duymamaktadır. Bunda öğretmenlerin toplumda oynadıkları rol ile birlikte aldıkları ücretlerin düşüklüğü ve diğer memurlara göre daha aşağıda hayat standartlarına sahip olmalarının da rolü olduğu düşünülebilir.

\section{2. Çalışma Koşulları}

Sait Faik Abasıyanık'ın eserlerine baktı̆̆ımızda, çalışma koşullarının kamu çalışanları ve işçiler açısından farklar içerdiğini görülmektedir. Genel olarak bir tanımlama yapmak gerekirse, kamu kesiminde çalışanların ve özellikle de bürokratların; oldukça rahat çalışma koşullarına sahip oldukları söylenebilir. İşçiler ise memurlara nazaran daha ağır şartlarda, neredeyse hiçbir güvenceleri olmadan çalışmaktadırlar. Fakat yine de düşük kademe memurların da rahat çalışma ortamlarına rağmen, sürekli bir bürokrasi içinde bulunmaktan muzdarip olduklarına dair izlenimlere de rastlanmaktadır. Eserlerde, çalışma şartları bakımından görülen bu memur-işçi ayrımı; yazarın iki tarafa yaklaşımını da etkilemiştir. Yazar işçileri genellikle bütün zorluklara rağmen mutlu ve kanaatkâr insanlar

YIL: 5 SAYI: 10 
olarak betimlerken memurlara, ister bürokrat olsunlar ister düşük seviyeli memur, hep mesafeli ve hatta negatif yaklaşmış bunları da yazılarına yansıtmıştır. Memurlar, öykülerde her zaman ifadesiz, huysuz ve soğuk karakterler olarak karşımıza çıkmaktadır. Aslında eserlerin geneline baktığımızda, bu özelliklerin yazarın devlete bakış açısını yansıttığını ve aslında bu özellikleri devlete ve kurumlarına atfettiğini görülebilir. Son olarak şunu da belirtmek gerekir ki Sait Faik, çalışma koşullarının fiziksel betimlemelerinden çok, bu koşulların çalışanlar üzerindeki etkileri ve çalışanların duyguları ile düşünceleri üzerinde yoğunlaşmıştır. Bu da bizlere fiziki verilerden ziyade, çalışma koşullarının psikolojik etkileri üzerinde bilgi edinme şansı tanımıştır.

\subsection{1. İşçilerin Çalışma Koşulları}

Sait Faik yazılarında işçilere ne kadar pozitif yaklaşmışsa, işyerlerine, özellikle de fabrikalara o kadar negatif yaklaşmıştır. Öykülerinde daha çok karakterlerin düşüncelerine ve hayallerine ağırlık veren yazar, işçilerin işyerleri hakkındaki düşüncelerini ve hayallerini bize yansıtarak; dönemin işçilerinin çalışma koşulları hakkında hissettiklerini bize aktarmıştır. Bunlar yazarın kendi gözlemleriyle birleştiğinde, yazarın eserleri çalışma koşulları açısından zengin bir kaynak olarak çıkmaktadır. "Semaver" isimli öyküde geçen "Bir haftadır fabrikaya gidiyordu. Rüyasında makineler, elektrik pilleri, ampuller gören, makine yağları sürünen ve bir dizel motoru homurtusu işiten... Ali işsten çıkmış gibi terli ve pembe idi" (Abasıyanık, 1936/2009f, s.9) cümleleri, fabrika hayatının sadece bir haftadır çalışan bir işçi üzerinde bile nasıl bir iz bıraktığının göstergesi olarak kabul edilebilir. Yine aynı öyküde geçen "Ali semaveri içinde ne 1stırap, ne grev, ne de kaza olan bir fabrikaya benzetirdi. Ondan yalnız koku, buhar ve sabahın saadeti istihsal edilirdi." (s.9) ve "Fabrikanın uzun ve bütün Haliç’i çınlatan düdüğü onda arzular uyandırır, arzular söndürürdü” (s.910) tanımlamaları, fabrikaların işçilerin bulunmaktan mutlu olmadıkları yerler olduğu şeklinde yorumlanabilir. $\mathrm{Bu}$, yazarın çalışana ve çalışmanın kendisine duyduğu saygıyla birlikte düşünüldüğünde, bunun en büyük sebebinin uzun çalışma süreleri ile ağır ve sağlıksız çalışma koşulları olduğu söylenebilir. 
Yazarın eserlerine baktığımızda, elbette kötü çalışma koşulları sadece fabrika işçileri için geçerli değildir. Sarnıç kitabının "Mavnalar" isimli öyküsünde, çımacının neden işten atıldığını anlatırken kullandığı "Bana eşşoğlu eşek dedi(iskele memuru), ben de çenesini dağıtıverdim. Arkadaşı; yapmamalıydın, dedi. Bu söz ötekinin o kadar gücüne gitti ki” (s.37) cümleleri, işçilerin daha üst mevkisinde çalışan kişiler ve memurlar tarafindan hakarete uğrayabildiklerini ve karşılık verdikleri takdirde işlerinden olabildiklerini göstermektedir. Yine bu şekilde bir hakaret olayına Birtakım Insanlar romanının kahramanlarından Ali Rıza'nın, çalıştığı teknenin sahibi olan Rafet Reis tarafından sık sık aşağılanması durumunda tanık olunmaktadır. Sarnıç isimli kitaptaki "Park" öyküsüne bakacak olursak yazarın "Etrafımda biri ceketli ihtiyar, öteki ceketsiz genç iki park temizleyici, hiç konuşmadan, kuru yaprakları süpürüyorlar” (s.65) gözlemi, işçilerin sürekli aynı işi zevk alamadan yapıyor olmalarının işçiler üzerinde yabancılaşmaya yol açmasının tipik örneklerinden biri olarak karşımıza çıkmaktadır. "Şahmerdan" hikayesindeki "Haziran rüzgarları birdenbire kesilmiş, yaz; rüzgarsız, ağır ve kasvetli iskelenin ve denizin üzerine çöküvermişti. C1garalar bitmişti. Tekrar iskelenin damı gölgesinden güneşin önüne çıkmak cesaretini, kendinde ilk Abdurrahman buldu" (Abasıyanık, 1940/2008d, s.11) cümleleri de işçilerin mevcut şartlar altında çalışmak istemediklerine dair açık bir izlenim yansıtmaktadır. Elbette, bu kadar memnuniyetsizliğe rağmen yazarın bir eserinde işçilerin daha iyi şartlara kavuşmak için mücadele etmiyor olmaları; dönemin gerçekleriyle birebir örtüşmektedir. Yazar durumu işçilerin kanaatkârlığı olarak aktarsa da, aynı grev ve örgütlenme başlığı altında da inceleneceği gibi "Cemiyetler Kanunu"nun ve onun yol açtığ 1 örgütlü işçi hareketinin eksikliğinin etkileri burada da görülebilmektedir.

Yazarın Şahmerdan kitabının "Çöpçü Ahmet” öyküsünde, Ahmet'in "Çobanlık yaptığı günlerdeki düşünmemenin yerine bugün süpürge sapına dayandığı zaman düşünmek, kötü kötü düşünmek geliyordu, neden acaba?” (s.59) sözleri kırdan kente gelmiş insanların, şehirdeki çalışma ilişkilerine alışmakta ne kadar zorluk yaşadıklarını ve şehir çalışmasının kıra kıyasla psikolojik açıdan ne kadar ağır olduğunu göstermektedir. Yine Birtakım Insanlar romanında köyden 14 yaşında gelmiş olan ve bir evde 
hizmetçilik yapan Zehra hakkında evin hanımının "Hizmetçi olarak sevdiği bu kızı gelini olarak görmektense... Böyle bir ihtimal dahi Lamia Hanım'ı iliklerine kadar üşütüyordu" (s.52) şeklinde aktarılan düşünceleri de işverenlerin çalışanlarına bakış açılarını yansıtan bir örnek olarak görülebilir.

Birtakım Insanlar romanında ada bekçiliğinin aktarıldığı bölümler, çalışma koşulları açısından ayrıca ele alınması gereken bir örnek olarak karşımıza çıkmaktadır. Ada bekçiliği, deniz feneri bekçiliği gibi tek başına, insan yüzü görmeden yapılan mesleklerden biridir. Bu roman da böyle bir işi uzun süre yapmanın kişi üzerindeki etkilerine dair çok ilginç tespitler barındırmaktadır. Bekçi Hrant'ın işi Hikmet'e devrettikten sonra içinden söylediği "Görüşürüz bakalım... 2 aya varmaz, karga bokunu yemeden uyandığın zaman nasıl bağırıyorsun: "Allahım! Bana bir insan gönder!" diye. Hani nerededir insan? Fırtına köpek gibi sesler çıkartır. Hele o pis martılar! O ne kötü sesli mahlûklardır. Görüşürüz, bekçi efendi, görüşürüz!” (s.118) cümleleri, bu tür bir çalışma şeklinin insanın doğaya karşı dahi nefret duymasına yol açtığını göstermektedir. Yine Hrant'ın "İnsanları sevmezken sever olduk. Hikmet Efendi biraderim, sever olduk! Boş bir adada yalnız kalmanın da bir hikmeti vardır" (s.118) sözleri içinde bulunduğu yalnızlığı açıklamaktadır. Romanın ilerleyen bölümlerinde de bu konuyla ilgili tespitler bu kez Hikmet üzerinden yürütülmeye başlamıştır. Yazar, Hikmet' in işinde geçirdiği ilk ayını "Bir uzun, korkunç, kimsesiz ay geçirdi. Aynaya baktığı zaman yüzünü sapsarı, gözlerini altını simsiyah şişmiş buluyordu. İçinde bir yorgunluk hissediyordu. Odun yarıyor, yer belliyor, sarnıç temizliyor, domuz ahırlarını insan oturabilir bir hale getirmeye çalışıyordu. Akşama yorgun; bir ateş yaktığı zaman, bu fiziki yorgunluktan ziyade daha iç taraflarında adeta akciğgerinde, karaciğerinde, midesinde, kafasında bir yorgunluk duyuyordu. Yalnız başına kimler, ne insanlar icat etmiş, onlarla neler konuşmuştu..." (s.121) cümleleriyle aktarmıştır. Söz konusu betimlemelerde, bu şekilde bir çalışma biçiminin insanın akıl sağlığına etkileri açıkça görülebilmektedir. Zaten yazarın yine Hikmet'le ilgili "Deli olmasına bir adım kalmıştı. O adımı atmamak için, aylığını almaya İstanbul'a indi” (s.121) cümleleri, yazarın da aynı tespiti doğruladığ kısım olarak karşımıza çıkmaktadır. 
Eserlerde bazı işyerlerinin çalışanlarına kalacak yer sağladıkları da belirtilmiştir. "Mavnalar" öyküsünde çımacı, Paşabahçe Cam Fabrikası'nda iş bulduktan sonra orada yatıp kalkmaya başlamıştır (Abasıyanık, 1939/2009e, s.37) cümlesi buna bir örnektir. Ayrıca iki öyküsünde kalacak yerlerin ayrıntılarına da yer vermiştir. Semaver kitabının "İpekli Mendil" öyküsünde fabrika bekçisinin kaldığı yer "Ben o zamanlar malların istif edildiği imalathanenin üstündeki bölümde yatardım. Odam ne güzeldi. Hele mehtaplı gecelerde ne şirin olurdu. Aşağı yukarı yaz kış pencereyi açık bırakırdım. Ne serin ne tuhaf rüzgârlar eserdi” (s.39) cümleleriyle açıklanmıştır. Burada iş̧inin kalığı mekân oldukça ferah olarak aktarılmıştır. "Türk Ülkesi” isimli öyküde ise bir şantiyede çalışan amelelerin şantiyede kaldığı kulübe "Bir yapı yerine düştüm. Yapı bir kenarda putrelleri, demir telleri, beton sütunları ile şimdilik bir harabe halinde. Köşeye tahtadan, küçük bir kulübe yapmışlar. Bekâr işçilerin barınmaları için herhalde; dışarıdan küçücük, şirin ama penceresiz bir yapı. İçerisini sonradan gördüm. Üst üste karanlık ve dar kerevetler koymuşlar, koğuş haline getirmişler. İçeride, penceresiz, dört köşe odanın içine, 35 kişiyi yığıvermişler. Bereket ki kocaman bir kapısı var. İçerideki ter ve insan kokusuna dışarının yaz gecesi su gibi girip çıkıyor. Bu yapının önüne gelince bir bağlama sesi duydum. Âşık hep yaylaların ve issız dağın insanının kelimelerini söylüyordu." (Abasıyanık, 1952/2009g, s.75) şeklinde betimlenmiştir. Aradaki fark dikkat çekicidir. Elbette "İpekli Mendil"de anlatılan ortamı yazarın birebir gözlemlememiş, ortamı kafasında tasarlamış olması bu farkın bir sebebi olarak görülebilir. Yine çalışılan mekânların ve yapılan işin farklılığı ya da yazarın iki kitabı yazdığı dönemlerde hayata bakışı açısından barındırdığı fark da etkili olmuş olabilir.

\subsubsection{Memurların Çalışma Koşulları}

Memurlar ve çalışma koşulları da yazar tarafından sık sık ele alınmıştır. İlgili bölümde incelendiği üzere memurlar genel olarak diğer ücretlilerden daha iyi ücret alan ve daha rahat şartlarda yaşayan insanlardır. Birtakım İnsanlar romanında "Doğançay İstasyonu'nda istasyon müdür idi...istasyon müdürünün sıcak odas1... Bir aralık Doğançay'da istasyon müdürlüğü yaparken yine böyle bir koltuğa yerleşip gazeteler okuduğunu

YIL: 5 SAYI: 10 
her zaman hatırlayacaktı... Oda sıcaktı. Bir dökme soba koca kavlan yarmalarını tüketir, tüketirdi." (s.18) şeklinde aktarılan betimleme memurların çalışma ortamlarının da işçilere nazaran çok daha rahat olduklarını göstermektedir. Fakat eserlerde bu rahatlık kendisini daha çok konfor olarak göstermektedir. Yoksa memuriyetin sıkı bürokrasisinin çalışanlar üzerinde yarattığı sıkıntıya eserlerde sık sık rastlanmaktadır. Memurlar yazarın hikayelerinde sürekli emir alan, emir veren ve sorumlulukları nedeniyle yeri geldiğinde insani görevlerini bile yerine getiremeyen insanlar olarak karşımıza çıkmaktadır. Bu gözlemlerin yazarın memuriyet hakkındaki olumsuz düşüncelerinin etkisinde kalmasıyla birlikte gerçekçi olduğu da söylenebilir. Yazar gerçekten de memurların bu durumundan duyduğu rahatsızlığı; "Şehrin Sabahları ve Adamlarından Biri" öyküsünde geçen "İşe gidecek, bir takım emirler alacak, emirler verecek, suratı kendisinden bok bir zavalliya haykıracaktır" (Abasıyanık, 1952/2009b, s.100) ve öyküyle aynı adı taşıyan kitaptaki "Son Kuşlar" öyküsündeki "Kahvecini kendisi sevimsiz bir adamdır. Kahveciden çok, ters bir devlet memuru hüviyetini taşır." (s. 10) örneklerinde görülebildiği gibi sık sık yazılarında aktarmaktadır.

Şunu da belirtmek gerekir ki devlet memurları arasında, yazar için öğretmenlerin yeri ayrıdır. Yazar öğretmenlere işçilere duyduğu sevecenlikle yaklaşmış, sık sık insani yönlerini ele almıştır. Semaver kitabının "Kıskançlık" öyküsünde geçen "Siz her gün dağda bayırdasınız. Ben, çocuklarla şu kümes gibi yerde pinekliyorum. Bir cumayı da sizin gibi geçirsem çok mu?” (s. 40) cümlesinde görülebildiği gibi eserlerde öğretmenlerin en büyük sorunlarından biri, uzun süre kapalı bir ortamda sürekli çalışmak zorunda olmalarıdır. Fabrikalar ve devlet daireleri de kapalı alanlar olmasına karşın köy okullarının basık, sıkıcı ortamının çevresiyle yarattığı tezatın öğretmenler üzerindeki etkisi kabul edilmelidir. "Köy Hocası ile Sığırtmaç" isimli öyküde geçen "Yakalayıp akşamüstleri köy kahvesinde bir saatçik ona ders verebilmek için bütün yaz uğraşmıştım. İşte bir haftadır akşamları onu kalın bileklerinden yakalarken ve saçlarını kavrarken içimde acayip bir kardeş muhabbetinin, bir ağaç gibi dallanıp budaklandığının farkına varmaya başladım." (Abasıyanık, 1940/2008d, s.79-80) ve "İki maaşımı hastalığına harcadığım talebe, sonbaharla bera- 
ber ölmüştü. Artık hiçbir zekâ beni alakadar etmiyor; küçük, nefes ve sığır kokan sınıfın pencerelerini, dağ rüzgârlarına açtırmak aklıma gelmiyordu. Köy birdenbire hasta talebemle birlikte gömülmüştü.” (s.80) cümlelerinde görülebildiği gibi; özellikle köy okullarında görev yapan öğretmenlerin tek başlarına yaşıyor olmalarının da etkisiyle çocuklarla aralarında güçlü bir duygusal bağ oluştuğu ve onları kardeşleri veya çocukları gibi görmeye başladıkları söylenebilir.

\subsection{3. İş Sağlığı ve Güvenliği İle İş Kazaları}

Yazar eserlerinde az da olsa iş güvencesine de değinmiştir. "İpekli Mendil" öyküsünde geçen "Yarın patron: "ulan üstüne ölü toprağı mı serpilmişti hayvan" diye kıçıma bir tekme, beni kovacağını bildiğim halde gık demedim." (Abasıyanık, 1936/2009f, s.39) cümlesi, "Çöpçü Ahmet" öyküsünde Ahmet'in düşüncelerini aktaran "İnsanı onbaşı çöpçülükten alıverirse, bu kalabalık içinde aç kalırsa” (Abasıyanık, 1940/2008d, s.59) sözleri gerek işçi gerekse de düşük rütbeli memur olanların kolaylıkla işten atılabildiğini göstermektedir. Dönemde İş Kanunu yürürlülükte olmasına rağmen, işçi hareketinin yükselmesini sağlayacak etkenlerin gerek yasalar yoluyla gerek de facto olarak engellenmiş olması bu durumun ortaya çıkmasındaki en büyük neden olarak görülebilir. Yine Lüzumsuz Adam kitabındaki “İp Meselesi” isimli öyküde bir ayrıntı olarak, hamalların elinden iplerini aldığınızda işlerini de tamamen kaybetmiş olduklarından bahsedilmektedir (s.34-35).

Sait Faik'in eserleri meslek hastalıkları ve işçi sağlı̆̆ı açısından da zengin bir kaynak olarak ortaya çıkmaktadır. Aynı zamanda dönemin İş Kanunu'nun işçi sağlı̆̆ ve iş güvencesi düzenlemeleri açısından yetersiz olmasının ve sosyal sigorta sisteminin henüz kullanılmaya başlanmamış olmasının etkileri de açıkça görülmektedir. "Beyaz Altın” isimli öyküde yer alan "Kâtip hastalıktan çökmüş halde: otur bakalım şu sandalyeye! Al eline kalemi, şu benim hesapları görüver. Deftere geçir. Şu mektubu da yaz. Kopyasını al. Ondan sonra da ziyafete başlarız" (Abasıyanık, 1939/2009e, s.26) cümleleri, işverenlerin işçilerinin sağlık durumları hakkındaki duyarsızlıklarının bir yansımasıdır. "Çöpçü Ahmet" hikâyesinde

YIL: 5 SAYI: 10 
Ahmet' in başına gelen bayılma olayını aktaran "Akşama doğru idi. Bugün ne kadar çok yorulmuştu. Küreğiyle süpürgesini Tophane'deki kulübeye bırakıp da kahveye yollandığı zaman bacaklarının kesildiğini, kafasının döndüğünü duydu. Bir şeyler oluyon, dedi ve yıkıldı. Köyünde kocakar1ların ve büyücülerin iyi edemediklerini nihayet şehre götürmeye karar verirlerdi. Şimdi, demin oracıkta bayılan Ahmet başka Ahmetmiş de sırtına onu bindirmiş, kasabaya götürür gibi, o Ahmet'e: Ahmet oğlum, dedi, sen buralarda, bu pis zanaatta edemicen" (Abasıyanık, 1940/2008d, s.60-61) cümleleri, şehir çalışma hayatının sağlık üzerindeki etkilerini ve işçilerin bu konudaki düşüncelerini aktaran bir gözlem olarak karşımıza çıkmaktadır. Mahalle Kahvesi kitabının "Kestaneci Dostum” öyküsünde geçen "Tam 7 ay hamallık yaptı. Ama bu işi bir türlü sevemedi. Yediği o kadar az bir şeydi ki bir gün ağır bir yükün altında ölmek bile aklına geldi. Yalnız soğuğu, sıcağı, açlığı hisseder...hararetinin 36,5tan öteye fırladığının bile farkına varmazdı. 40 derece ateşle valiz beklediği bir gün düşüvermiş. Sarhoş sanmışlar, karakola götürmüşler” (s.91) cümleleri çalışma şartlarının bazen işçilerin kendi sağlık durumlarının farkına varamayacakları kadar ağırlaşabildiğini aktaran bir örnektir.

Yukarıdaki örneklerin de gösterdiği gibi işçilerin sağlık sorunları sektörden sektöre az da olsa farkl1lık gösterse de sağl1k güvencelerinin olmayışı hepsi için geçerlidir. Örneğin, yol işçilerinin yaşadıklarına değinen "İnsanlar, Türküler ve Masallar" öyküsünde geçen "Her akşam bir hendeğin kenarına ateşlerini yakarlar. Cin, dev hikâyeleri anlatarak gecenin içinde sabahı bekleşirler, türkü söylerlerdi. Durmadan türkü söylerlerdi. Uzakta yol bekçisinin çadırında, çay ibriği kaynarken, bazı akşamlar birdenbire köylülerin sesi kesilirdi. O zaman yolu gezmeye gelmiş 5 müteahhitten bir tanesi yol bekçisine, kolbaşıya bakar: Ne var Hüseyin? Derdi. Hüseyin cevap vermezdi... Muhakkak birisi öldü. Bu saatte türkü söylemeseler masal anlatırlar. Masal anlatmasalar güreş ederler. Masal anlatıldığ 1 , güreş edildiği zaman da bu kadar sessiz durmazlar. Gülüşürler, alay ederler, bahis tutarlar. Muhakkak bir ölü var" (Abasıyanık, 1952/2009b, s.87-88) cümleleri işyeri güvenliliğinin ve işverenin işçiye karşı sorumluluklarının dönemdeki vahim durumunu yansıtmaktadır. Yine aynı öyküde geçen "15ini bazen 20 sini yine müteahhidin zeytin ekmeğine harcayan 
40 kuruş gündelik alan ameleden bazıları ne kadar kuvvetli ise bazıları o kadar narin, zayıf insanlardı. Birdenbire, arkadaşlarının yanında küçük düşmemek için, enerjilerini toplarlar, onlar da saatlerce, günlerce türkü söyleyerek çalışırlardı. Ama sonunda bir gün yatarlar. Üşürler, titrerlerdi. Bu belik gizli bir sitma, belki de galopan veremdi, belli olmazdı" (s.88) cümleleri, bu sektörde işçi alımında hiçbir sağlık muayenesine gidilmedi$\breve{g i}$, işçilerin hayatlarının kolaylıkla riske atıldığının bir göstergesidir. Yine Birtakım Insanlar romanında trendeki dalgııın anlattıkları dalgıçlık mesleğinin ne kadar tehlikeli olduğunu göstermektedir

Dalgıcın, vurgun yiyip sakatlanan arkadaşlarını anlattığı "Şimdi İzmir'dedir, bizim cemiyet, arkadaşlar ona bakıyoruz. Bakıyoruz ama neye yarar?" (s.62) sözleri yine sosyal güvenlik eksikliğinin bir yansıması olarak karşımıza çıkmaktadır.

Sait Faik bir öyküsünü doğrudan iş kazaları üzerine yazmıştır. Lüzumsuz Adam kitabının "Mürüvvet” isimli öyküsü, bir fabrikada yarma makinesinde çalışan işçilerden birinin elinin kaybetmesi ve üzerine gelişen olayları anlatmaktadır (s.24-35). Bu hikâye, dönemde işçilerin hiçbir güvenceye sahip olmayışlarını ve o dönemde iş kazalarının sonuçlarını anlatması açısından önemli bir kaynaktır. Hikâyede yaralanan arkadaşlarına ilk müdahale edenlerin işçiler olması ve bu müdahaleyi yaparken yaralanan işçinin elinin saracak hiçbir şey bulamamaları fabrikaların iş güvenliği açısından ne kadar yetersiz olduğunu sözler önüne sermektedir. 4 gün sonra işçi Hüseyin'in hastanede kolunun kesilmesi üzerine yaşadıkları "Bir tazminat lafıdır tutturdu... Üç bin papel demez mi? Eşşoğlu eşek, dedim, hıvvan! Katı! Dedim, 3000 panganot bir kola kim verir be? Sonra düşündüm kendi kendime "Osman, sen kolunu verir misin birisi 3000 lira verse?" Ben vermezdim. O zaman Hüseyin' in senden neyi eksik; neden versin?" (s.27-28) konuşması, işçilerin kendi hakları hakkında ne kadar az şey bildiklerini göstermekle birlikte, bir işçinin hakkını arayan başka bir işçiye ilk verdiği tepki bir işçi mücadelesinin olmayışının işçiler üzerinde bıraktığ1 etkileri göstermesi açısından düşündürücüdür. İşçilerin tazminat davası için avukatla görüşmeye gittiklerinde avukattan aldıkları "Parasız dert dinlenmez. 100 liranız varsa işe başlayalım" (s.28) cevabı da işçilerin hak arama yollarındaki bir engeli gözler önüne sermektedir.

YIL: 5 SAYI: 10 
Hikayenin sonunda olayın kapanmasını ise yazar şu cümlelerle aktarmaktadır: "Bizim patron sakinleşmişti. Kasasını açtı. Bana: Sen, dedi, ömründe 3000 lirayı bir arada gördün mü? Cevap vermedim. Sonra tatll1ıkla: Osman Ağa, dedi, en büyük gördüğün para kaç liralıktır? Ellilik gördüm beyim! Bir deste para çıkardı. Masanın üstüne atmaya başladı. Hani istemeye istemeye sersem sersem saydım...60 lira. Bu para, dedi, o şoparı ölünceye kadar idare eder. O Çingene be! Onlar senede 50 lira harcarlar $\mathrm{m}$ sanırsın? Diyelim harcasınlar. Bu para 60 sene sürer. Kaç yaşında o? 18. Demek ki, dedi, herifi 75 yaşına kadar besleyeceğim ha? Namussuz herif(avukat için) 300 liramı kopardı. O zaman bilmiyordum. Bu oğlanın babası da aynı boku yemiş. Güya bilmeden dolapta kalmış, döndürmüşler, ölüsü çıkmış deyyusun. Bunlar öyledir. Mahsus yapıyorlar.Osman Ağa, dedi, al sana 150 lira ve şuna gitsin çergisine! Beyim, dedim, bir kol omzundan gitti. Bu herif nasıl çalışır? Buna biraz daha ikram yap! Osman Ağa, dedi, bunu senin hatırın için veriyorum. Beş para fazla vermem. Sen onun ağzını bir ara. Sahiden bu iş istemeyerek oldu ise 150 lira daha vereceğim... (Hüseyin) ,Te be! Dedi, üyle olsa ne lazım, be! Bana 300 de yeter be! İki kısrak alırım be! Canımı sokakta bulmadım ben, Osman Ağa be!... Ertesi günü 150 lirayı götürüp patrona geri verdim. Sonracığına pişman oldum. Bir hesap ettim. Haşim senede en az 300000 lira kazanıyordu. 300 lirayı Şopar Hüseyin'e çok görmüştüm.” (s.29-30). Bu yöntemin o dönemde ortalıkta neredeyse hiçbir sosyal güvenlik önlemi yokken, olanlar da kullanılamıyorken böyle birçok vakanın çözümünde işverenler tarafinda kullanıldığı ortadadır. Yazar bize sadece bunun örneklerinden birini aktarmıştır. Aynı zamanda burada da yine işverenlerin işçilere bakış açısı açıkça görülmektedir.

Yazarın bazı eserlerinde, işçiler arasında dayanışma duygusuna da yer verilmiştir. Örneğin "Şahmerdan" isimli öyküde "Öteki kolda iki hemşeri oldukları sözlerinden anlaşılan iki hamalcıdan birisi acınacak zayıflıktaydı. O da bütün işi arkadaşına bırakmaya çalıştığ i için kızarmıştı. Arkadaşı is ona en küçük kuvvet sarf ettirmemek için elinden geleni yapıyordu" (Abasıyanık, 1940/2008d, s.10) şeklinde anlatılan olayda, çok ağır şartlarda çok ağır bir iş yapan işçilerin bile aralarında güçsüz olanı koruduğu görülmektedir. Yine "Mürüvvet" hikâyesinde, Hüseyin yaralandığında bütün 
işçilerin yardım için koşması bir dayanışma örneği olarak gösterilebilir (Abasiyanık, 1948/2009c, s.25-26)

Elbette eserlerde kaçınılmaz olarak, işyerindeki rekabetten ve işçiler arası çekişmelerden de bahsedilmektedir. "Şahmerdan” isimli öykü bu konuya ilişkin ilginç ve trajik bir olay anlatmaktadır. Öyküde şahmerdanı çalıştıran iki işçi arasındaki çekişme "Bir cıgara molası sırasında sarışın amele yardımcısı Salih'e: bana bak ulan, dedi, numaracı! Beni eşek yerine alma. Namusumun hakkı için, bir kafam kızarsa, atarım denize seni. Salih, amele başı mevkiinde olan Karahisarlı'nın komşusuydu. Zor işlerden kendini ancak bu sayede ve kancıklıkla kurtarabiliyordu. Şimdi dört amele nefes nefese idiler. Salih'in arkadaşı, sarı yulaf saçlı Abdurrahman, Salih'e dik dik baktı. Deminki duraklamanın sebebi oydu. Ulan kahpe, dedi. Karahisarlı: Kime diyon ulan, dedi, o lafi? Abdurrahman bu adamdan çekinirdi. İstese parasını bile vermez; bu kimsesiz, ne idüğü belirsiz, lakayt iskelenin köyünde Abdurrahman'1 perişan bırakabilirdi. Anama, dedi. Neden? Neden olacak, dedi, beni doğurduğundan.” (Abasıyanık, 1940/2008d, s.11-12) cümleleriyle aktarılmaktadır. Görüldüğü gibi işçiler arasındaki çatışmanın asıl nedeni kendisi de işçi olmasına rağmen işveren temsilcisi sıfatıyla orada bulunan amele başının, işçilerden birini iş yapmadığı halde kolluyor olmasından kaynaklanmaktadır. İşçilerin iş güvencesinin olmaması da bu anlaşmazlığı içten içe büyütmektedir. Zira olaylar öykünün ilerleyen kısmında olaylar "Bir ara zınk diye durdular... Abdurrahman hızla bir yarım sağ döndü. Arkadaşı Salih'i müthiş bir tekme ile denize yuvarladı. Kendisi de sırtüstü, ağzından kan boşanarak iskelenin tahtaları üzerine düştü. Salih yüzme bilmediği için on dakika içinde boğulmuştu. Abdurrahman'ı hastaneye kaldırdılar" (s.13) şeklinde gelişmiştir. Her ne olursa olsun işverenden kaynaklanan işçi anlaşmazlıklarının böyle sonuçlar doğurma ihtimali olduğu görülmektedir. Birtakım Insanlar romanında geçen "Çünkü oranın hamalları -her yerin hamalları gibi- yabancıyı pek sokmuyorlardı” (s.132-133) cümlesi de işçilerin ekonomik nedenlerden dolayı birbirlerine ayrımcılık yaptıklarını aktaran bir örnek olarak, işçi çatışmasını farklı bir yönden ele almaktadır.

YIL: 5 SAYI: 10 


\subsection{4. Çalışma Süreleri}

Yazarın yazdığı yüzden fazla öyküye rağmen, eserlerinde çalışma saatlerine ilişkin verilere çok nadir rastlamaktayız. Fakat yine de bu veriler dönemin çalışma sürelerine ilişkin genel bir çerçeve oluşturmak için yeterli görülebilir. Dönemin temel özelliğinin aslında bugün de hala varl1ğını sürdüren erkenden güne başlamak zorunluluğu olduğu söylenebilir. Elbette gerek yazarın eserleri gerek diğer kaynaklar köylerde ve adalarda da insanların çok erken saatte güne başladıklarını göstermektedir ve elbette bu insanlar da gün içinde çok yorulmaktadır. Fakat şehirde yaşamanın ve devlet memuru olarak ya da endüstriyel üretim süreci içerisinde işçi olarak çalışmanın getirdiği ekstra psikolojik ve sosyal yorgunluğun varlığ dikkate alındığında ücretlilerin ne kadar az dinlenebildikleri daha açık ortaya çıkmaktadir.

Sait Faik' in öykülerinde, uykusuzluk ücretlilerin en büyük sorunlarından biri olarak aktarılmaktadır. Bütün gün çalışıp, yorgunluktan hemen uyuyan insanların sabah daha güneş doğmadan uyanmasıyla sık sık karş1laşılmaktadır. Örneğin Lüzumsuz Adam kitabındaki "Birahanedeki Adam" öyküsünde geçen "Yüzünün bazı yerlerinde sakal artıkları vardı. Demek ki uyku sersemi tıraş olacak, yine uyku sersemi sokağa firlayacak kadar işe gecikmemesi lazım gelenlerden biri. O halde, kendi işinin sahibi değil.” (s.20) cümleleri, erken kalkmak zorunluluğunun ücretliler üzerindeki fiziksel etkilerinin bir gözlemi olarak karşımıza çıkmaktadır. Gerçekten de yazarın burada, kişinin yüzündeki sakal artıklarından yola çıkarak kendi işinin sahibi olmadığı yorumunu yapması manidardır. Yine Mahalle Kahvesi kitabındaki "Bir Bahçe" öyküsünde geçen "Biletçiyi, uyku sersemi biletçiyi, ilk tramvay arabasının çalışkan insanlarını..." (s.80) tanımı ve Alemdăg'da Var Bir Yıla kitabındaki "Panço'nun Rüyası" isimli öyküde geçen, Panco'nun söylediği "Yanız sabahları işte böyle bir türlü kalkamam." (s.29) cümlesi; ücretliler için yeterince uyuyamama problemini gözler önüne seren anlardan biridir. Havuz Başı kitabının "İnsanlar, Türküler, Masallar” öyküsünde (s.80) ve Kayıp Aranıyor isimli romanda (s.9) da yol işçileri ve balıkçı teknesinde çalışan işçiler özelinde, daha güneş doğmadan çalışmaya başlayan işçilerden bahsedilmektedir. 
Yazarın öykülerinde çalışma saatleriyle ilgili tespitlerinden bir tanesi de kişiye çalışmaktan, kendisine ya da arkadaşlarına ayırabileceği zaman kalmamasıdır. Örneğin Şahmerdan kitabındaki "Satılık Dünya" öyküsünde bir devlet memuru için, çocuğunun öldüğü günde dahi "O gün öyle bir iş vardı ki, akşama kadar yemek yemeğe vakit bulamadı." (s.77) şeklinde yaptığı tespit; durumun trajikliğini yeterince açıklamaktadır. Yine, Sarnıç isimli kitaptaki "Mavnalar" isimli öyküde aynı evde hatta aynı odada yaşamalarına rağmen birbirlerini göremeyen iki işçiden bahsetmektedir (s.35-37). Yazar, zaten bu durumla ilgili düşüncelerini de Kayıp Aranlyor romanında "Ertesi günü yapacak işleri içinde hep aynı olanı bir yana bırakırsak bize saat olarak ne kalır?" (s.66) cümlesiyle açıklamıştır. Zaten yazarın kahramanları da sık sık, özellikle de erken kalkmak zorunda olmalarıyla ilgili olarak bu durumdan şikayet etmektedirler.

Hikayeler de karşımıza çıkan ayrıntılardan bir tanesi de uzun çalışma saatlerine en çok maruz kalanların çocuk işçiler olduğudur. İlgili bölümlerde değindiğim gibi çocuk işçiler aynı işte çalş̧an bir yetişkinden daha az ücret aldıkları gibi daha uzun sürelerce çalıştııılmaktadırlar. Yazar bu konuyla ilgili özellikle "Dondurmacının Çıră̆ı" öyküsünde ayrıntıya yer vermiş ve "17 saat çalıştıktan sonra bu iki çocuğu 5 saatlik bir uykudan..." (Abasıyanık, 1952/2009g, s.98), "Ama küçük İmrozlu çocukların sabahın saat beş buçuğundan gecenin saati birine kadar çalışmalarının..." (s.98) cümleleriyle çocukların ne kadar zor durumda kaldıklarını aktarmıştır.

Son olarak, yazar bazı meslek gruplarının diğerleri kadar erken kalmak zorunda olmadıklarına da öykülerinde değinmiştir. "Mavnalar" isimli öyküdeki değirmen amelesinin öğleden sonra işe başlıyor olması (Abasıyanık, 1939/2009e, s.37) ile Kayıp Aranıyor romanının başkahramanı olan gazeteci Nevin'in işe saat 10 'da başlıyor olması bu duruma örnek olarak gösterilebilir (s.9).

\section{3. Çalışma Yaşamında Kadın ve Çocuk İşçiliği}

Sait Faik'in eserleri söz konusu olduğunda kadın çalışmasına dair neredeyse hiç veri olmadığını söylemek gerek. Hatta Kayıp Aranıyor romanının başkarakteri kadın bir gazeteci olmasında rağmen, kitapta bu kadının

YIL: 5 SAYI: 10 
çalışma yaşamına dair en azından kadın olarak çalışma hayatına dair hiçbir ize rastlanılmamaktadır. Buna karşılık çocuk çalışırıılması söz konusu olduğunda Sait Faik'in zengin bir kaynak olduğu söylenebilir. Kendi yaşadığ 1 veya dinlediği olayları aktaran bir yazar olarak, Sait Faik birçok öyküsünde çocuk çalışanlardan bahsetmiştir. Zaten o dönemde özellikle çırak olarak çocuk çalıştırılmasının oldukça yaygın ve ayrıca çocukların aileleri tarafından teşvik edilen bir çalışma şekli olduğu tahmin edilmektedir ve bu durum yazarın eserlerine de aynı şekilde yansımıştır.

İncelenen eserlerde kadın çalışmasına dair tek açık bilgiye Birtakım Insanlar romanında rastlamaktayız. Romanın geçtiği adanın berberi Dmitro'nun yanına çırak olarak verilen Melek için berberin Melek'in babasına yaptı̆̆ " Işsi senesine kalmaz öğrenir. Kızların eli bu işe daha yatkındır" (s.13) yorumu o dönemde, şaşırtıcı olmayan bir biçimde kadınların yapabileceği işler-erkeklerin yapabileceği işler ayrımı olduğunu göstermektedir.

Yazarın öykülerinde karşılaştığımız çocuklar, genelde 14-15 yaşlarında işe başlamaktadırlar. Döneme dair yapılmış olan incelemeler göstermektedir ki yazarın eserlerini yazdığı yıllarda 12-16 yaş arası çocukların işgücüne katılımında, 2. Dünya Savaşı'nın da etkisiyle, büyük bir artış olmuştur (Makal, 1999, s.310). Elbette bu veriler endüstriyel çalışmaya yönelik olmakla birlikte, genel olarak çocukların çalışmaya başlama yaşlarıyla ilgili bir fikir verebilir. Fakat Havuz Başı kitabındaki "Sur Dışında Hayat" isimli öyküde 8 yaşında bir araba tamircisinde çıraklığa başlamış bir çocuktan bahsedilmektedir (s.77). Bu bir istisna gibi gözükse de çalışma yaşını korkutucu derecede aşağ çektiği ortadadır.

Eserlerde çocuk çalışması karşımıza genelde "çıraklık" şeklinde çıkmaktadır. Neredeyse öykülerdeki her esnaf yanında çırak çalıştırmaktadır. Özellikle yaz aylarında, yani okul tatil olduğunda hemen her çocuktan çalışması beklenmektedir. Bu da gerçekten çok çeşitli alanlarda çocuk emeği ile karşılaşmamıza neden olmaktadır. Semaver kitabının "Garson" öyküsündeki kahveci (s.63-67), "Lüzumsuz Adam" hikâyesindeki işkembeci (Abasıanık, 1948/2009c, s.9-16), yine Mahalle Kahvesi kitabındaki “Kestaneci Dostum” öyküsündeki kahveci (s.89-94), Son Kuşlar 
isimli kitabında "Dondurmacının Çırağı" öyküsündeki dondurmacı (ki bu öykü doğrudan çocuk emeğini konu almaktadır) (s.96-102) ve Birtakım Insanlar romanındaki birçok değişik sektördeki esnaf çırak çalıştırmaktadır (s.11-14). Ayrıca Kumpanya isimli kitabın “Kriz” öyküsünde görülebildiği gibi, çocuklar hamallık gibi ağır işlerde de çalışabilmektedirler (s.75). Semaver'de bulunan "Garson" isimli öyküde geçen "Kahveyi açtıktan bir hafta sonra semtin çocuklarından bir tanesi, kendi kendisine gelir. Ahmet bir şey söylemeden çıraklık vazifesini alırdı." (s.65) cümleleri, çocukların da erken yaşta çıraklık yapmaya başlamaları durumunu kabullendiklerini göstermesi açısından ilginç bir gözlemdir. Zaten Birtakım İnsanlar kitabında “Ada'da adettir. Fakir her erkek çocuk bir bakkal, sütçü, ekmekçi, pastacı, kasap veya berber yanına çırak alınır. Kimse dışarıdan çırak getiremez. Ta ki, Ada çocuklarının hepsi iş bulsun..." (s.11-12) ifadeleriyle dile getirildiği gibi ailelerin maddi durumu ve bu nedenle çocuklarını çalışmaya teşvik etmeleri, çocukların durumu kabullenmelerinde şüphesiz etkili olmaktadır.

Çocuklarının bir meslek öğrenmesi ailelerin çocuk çalışmasını özendirmesinin bir nedeni olsa da eserlerde de açıkça görülmektedir ki bunun asıl nedeni ailelerin ekonomik durumudur. Öykülerde çalışan çocukların pek çoğunun ailesinin ona bakacak gücü dahi yoktur. Bu da çalışan çocukların genellikle ya hiç okuyamamalarına ya da öğrenimlerini yarıda bırakmış olmalarına yol açmaktadır. Örneğin, Şahmerdan kitabının "Projektörcü” isimli öyküsündeki projektörcü çocuğu için "Yaş 39, oğlum 15 yaşında. Mektepte hocaları bayılırlardı. Bana hep söylediler. Okusun okusun diye. Ama biz fakir insanlarız, nasıl okutalım beyim? Hem herkes okursa sanatı kim yapacak; öyle değil mi ya? Yeter işte ilk mektebi bitirdi. Orada marangoz yanına verdik haftada 4-5 lira alıyor. Az para mı? Ama hala elinden kitap düşmez, hala okur. $\mathrm{O}$ da benim gibi eski gazete tiryakisidir." (s.45) cümlelerini kullanmıştır. Bu aslında kendisi okumak isteyen ve ailesinin de okumasını istediği bir çocuğun erken yaşta çalışmaya başlamak zorunda kalmasına iyi bir örnektir. Kumpanya isimli kitabın "Kriz" adındaki öyküsünde de, hikâyenin kahramanı Necmi 12 yaşlarında iki tane hamallık yapan çocukla tanı̧̧mıştır. Çocuklardan biri okula gitmemesinin sebebini "Ben mi? Ayakkabım yok." şeklinde açıklarken diğeri "Para yok.

YIL: 5 SAYI: 10 
Kitap, defter, kalem parası. Önlük parası. Önlüksüz mektebe almıyorlar. Gidiyordum; önlük al da sonra gel diye bir gün söylediler. Ertesi gün yine gittim önlüksüz; almadılar. Annem önlüğü yaptı. Yakasının beyazını bulamadık. Kitap parası da lazımmış. Biz de vazgeçtik.” (s.77) cümleleriyle açıklamaktadır. Bu örnekler göstermektedir ki, ailelerin kötü maddi durumu çocuğun erken yaşta çalışma hayatına itilmesine sebep olduğu gibi okula gitmelerine de engel olmaktadır.

Eserlerde çocuk çalışanların aldıkları ücretler genelde birbiriyle yakınlık göstermektedir. Ücretlere ilişkin bilgilere pek çok eserde ulaşmak mümkündür. "Orada marangoz yanına verdik haftada 4-5 lira alıyor, "Sanırım ki bu saatlerde 1-2 lirayı doğrulturlardı", "Dmitro'nun yanında haftalığ 4 liraya çıkan Melek, "Hikmet haftalığının(6 lira) 1 lirasını yanında çalışan çocuğa verir." gibi örnekler; bize o dönem çocukların ücretlerinin haftalık 1 ile 7 lira arasında değiştiğini ve ücretlerin süreklilik arz etmediğini göstermektedir (Abasıyanık, 1940/2008d, s.45; 1952/2009g, s.99; 1944/2008b, s.21 ve s.23). Eserlerdeki diğer bilgiler göz önüne alındığında, çocuk çalışanlar aynı miktarda emek isteyen işler yapan yetişkinlere göre daha az ücret almaktadırlar. Bu ileride değinilecek olan, çocukların çalışma saatlerinin esnek ve genelde bu esneklikten kaynaklı yetişkinlere nazaran daha uzun olması ile birleşince; ortaya çocuk emeğinin sadece kullanılması değil, daha çok sömürülmesi gibi bir durum çıkmaktadır. Fakat yine "Sur Dışında Hayat" isimli öyküdeki bir istisna göstermektedir ki çocuklar da bazen çok iyi ücret alabilmektedir. Söz konusu hikâyede bahsi geçen, araba tamircisinin yanında çıraklık yapan çocuk; günde bir araba boyamaktadır ve karşılığında 40 lira kazanmaktadır. Elbette bu bir istisna olup, tamamen çocuğun çizim yeteneğiyle ilgilidir (Abasıyanık, 1952/2009b, s.77-78).

Gerek ücretlerin düşüklüğü, gerek çocukların ailelerinin maddi yoksunlukları nedeniyle çalışmak zorunda kalmış olmaları; çocuk çalışanların yaşam standartlarının çok düşük olmasına yol açmaktadır. "Kriz" öyküsünde, yazarın hamal çocukları "Bunların birisi 12 yaşlarında gözüken bir çocuktu. Muhacir olduğu evvela mintanından belliydi. Bu çocuğu üstünde uzun bir ceket vardı. Pantolonu, golf yapabilmek için uğraşmıştı. Kınnap bağlanmış yırtık ve büyük potinleri vardı ayağında. İlk bakışta fena giyin- 
memiş hissini veriyordu. Fakat biraz daha dikkatle bakınca büyük, iğreti bir ihtiyar ceketini altında hiçbir şey olmadığı anlaşılıyordu. Ceketin akalarını kaldırmış ve bir çengel iğne ile boynu hizasına iğnelemişti. Diğeri de 12-13 yaşlarındaydı. Ceketini anasının çalıştığı evden verdikleri nasıl belli oluyorsa..." (Abasıyanık, 1951/2006, s.75-76) şeklinde betimlemesi ve "Bir Sonbahar Akşamı” isimli hikayede geçen “...hamal çocuğun çıplak ayaklarındaki renkten çizmeler..." (Abasıyanık, 1952/2009b, s.29) tanımlaması, çocuk çalışanların ne kendilerinin ne de ailelerinin kendilerine bir ayakkabı bile alacak durumda olmadıklarını, karınlarını zor doyurdukların1 göstermektedir. Yazar, Birtakım İnsanlar romanında kısaca, bir balıkçı teknesinde çalışan çocuğun hayatını "Hikmet haftalığının(6 lira) 1 lirasını yanında çalışan çocuğa verir. Çocuğun yemeğini bereket Ruhi Kaptan evinin artıklarıyla üzerine almıştır. Çocuk ambarda yatar, fakat sabahları türkü çığırarak uyanır. Gözleri her zaman uykuludur. Gözlerinin altı her zaman çürüktür... Rüya görecek zamanı gelmiştir ama Ruhi Kaptan'ın artıklarıyla bu rüyayı daha birkaç sene göremeyecek. Çocuğun yapısı zayıftır. Böbrekleri bozuktur. Rutubet zayıf bünyesine göre değildir.” (s.23) cümleleriyle anlatmıştır. Bu örnekte de görüldüğü gibi bazı çocuklar çalışmak için evlerinden uzakta, çok daha zor şartlar altında yaşamak zorunda kalabilmektedirler. Ayrıca bu örnekte çocuğunun sağlığının yerinde olmaması bir yana, olsaydı bile bu şartlar altında daha fazla koruyamayacağı da söylenebilir. Çocuk bedenlerinin hastalıklara karşı dirençlerinin yetişkinlere nazaran daha az olması, çocuk çalışmasının çocuklar için tehlikelerini daha da arttırmaktadır. Yine bu örnekte yazarın, "çocuğun bu şartlar altında rüya göremeyeceği” şeklinde yaptığı betimleme, abartı gibi gözükse de durumu özetlemektedir. "Kestaneci Dostum” öyküsünde bahsi geçen çırak için yapılmış "Anası da öldükten sonra, ninesinin Kahveci Salim Usta'nın yanına verdiği bu kavruk çocuk belki 10 seneden fazla Salim Usta'nın yanında kalmış, bu 10 sene içinde onun hiç büyümediğini bütün müşteriler fark etmişti(24 yaşında)." (Abasıyanık, 1950/2009d, s.89-90) tanımlaması da hayli ilginçtir. Bu ifadeler, yukarıda bahsedilmiş olan şartlarda büyümüş olan çocukların, fiziksel olarak olması gerektiği ölçüde gelişemediklerine dair bir gözlem olarak kabul edilebilir. Son olarak Birtakım Insanlar adlı romanda, çocukların ücretlerine ilişkin ilginç bir tanımlama yer almaktadır. Yazar, esnafın çocuklar hakkındaki düşün-

YIL: 5 SAYI: 10 
celerini aktarırken “...2 lira haftalıklarını aylarca biriktirdikten sonra yaz bitene yakın hepsinin sırtlarında bir mavi gömlek, ayaklarında bir beyin verdiği büyük ayakkabı vardır. Şimdi beyaz, kar gibi pantolonlarıyla onlar da arabacı çocuklarına karışabilirler. İşte o zaman da Karamanlı'nın dükkânından gaz tenekesi, sebzecinin şeftalileri, kavunları, ekmekçinin ekmekleri, pastacının kurabiyeleri eksilir. İşte bunun için haftalıklarını hemen yiyen çıraklar en makbul çıraklardır” (s.12) cümlelerini kullanmıştır. Burada esnafın, parasını biriktirip kendi ihtiyaçlarını gideren çocuklara negatif yaklaşımı ortaya konmaktadır. Bu gerçekten nedeni aranması ve tartı̧ılması gereken bir konudur.

Yazarın eserlerinde, çocukların çalışma saatlerinin esnek ve uzun oldukları görülmektedir. Bu esnekliğe yol açan en büyük etkenin, öykülerdeki çocukların çoğunun çırak olarak çalışması; geri kalanlarının da balıkçı teknelerinde ya da hamal olarak çalışıyor olması söylenebilir. Ayrıca çocukların zaten sözleşmeye bağlı çalışmıyor olması, hem çalışma saatlerinin hem de ücretlerin esnetilmesine zemin hazırlamaktadır. Çocuk çal1şanlar işe başlama saatleri bakımından diğer ücretlilerle pek bir farklılık göstermemektedirler. Onlar da sabahın erken saatinde, uykularının alamadan işe gitmek zorunda kalmaktadırlar. Yazarın çocukların çalışma saatlerine ilişkin en açık gözlemleri Son Kuşlar kitabındaki "Dondurmacının Çırağı" öyküsünde yer almaktadır. Yazar, bu öyküde "17 saat çalıştıktan sonra bu 2 çocuğu 5 saatlik bir uykudan terütaze, kaygusuz nasıl kalktıklarını...merak edemez miyim? Ama küçük İmrozlu çocukların sabahın saat 5 buçuğundan gecenin saati 1ine kadar çalışmalarının onlara sağladı̆̆ı... mükafat, her hafta papaz efendinin dükkanı tütsüleyip okuduğu dua karşılı̆̆ında aldığının tam yarısıydı. Bereket ki öğleüstleri sıcak, küçük köyü 4 tarafından sardığı zaman, iş biraz hafifliyor, masaların üstüne kıvırcık kafalarını esmer ve çilek kokulu kollarının arasına alıp uyuyabiliyorlardi. Sonra saat 3e doğru iş yeniden bütün hızıyla başliyordu" (s.98-99) cümleleriyle bize çalışma saatleriyle ilgili ayrıntılı bilgiler vermektedir. Gerçekten günde 5 saat uyuyup 17 saat çalışmak değil bir çocuk için, yetişkin bir insan için bile kabul edilemeyecek bir çalışma süresidir. Üstelik bu çocukların bu saatler içerisinde her türlü taşıma işini de yapıyor olmaları durumun vahametini arttırmaktadır. Aynı zaman da yine bu örnekte de çocukların ücretlerinin düşüklüğüne atıfta bulunulmuştur. 
Sait Faik'in eserlerinde endüstride çocuk çalışmasına dair hiçbir veri bulunmadığına bu araştırmada daha önce değinilmiştir. Bu nedenle bu alandaki çalışma koşulları hakkında da herhangi bir bilgi bulunamamıştır. Fakat eserlerde bahsedilen çocuk çalışanların, çocuklar için ağır şartlarda çalıştığı söylenebilir. Birtakım İnsanlar romanındaki "Üstleri yağl1, ayakları çıplak, belleri çökük, yazın koca yokuşları damacanalarla, sırtlarına yüklendikleri fanilalardan suları akan buzlarıyla, zeytinyağı tenekeleriyle, sepetlerle her şeyi bu çocuklar taşır. Dükkânların önünü onlar süpürür" (s.12) ve yine çocuk çalışması konusunda yazarın eserleri arasında en önemli referans olarak adlandırılabilecek olan "Dondurmacının Çırağı" hikâyesindeki "17 saat çalıştıktan sonra bu 2 çocuğu 5 saatlik bir uykudan terütaze, kaygusuz nasıl kalktıklarını, tekrardan dondurma kutusunu saatlerce durmadan nasıl çevirdiklerini, bir zeytinyağl1, üstüne yoğurt bile dökülmemiş bakla yedikten sonra, kurşun gibi ağır dondurma kutularını zengin ve insafsız dondurmacının evinden dükkâna hangi esrarengiz kuvvetler taşıdıklarını merak edemez miyim?" (Abasıyanık, 1952/2009g, s.98) ifadeleri çocukların, ağır işlerden uzak tutulmadıklarını; aksine bu işlerin genelde düşük ücretle çalıştırılan çocuklara yaptırılmasının tercih edildiğini göstermektedir.

Çocuk çalışanlar zaten kayıtdışı olarak çalışıtırldığından hiçbir sağlık ya da iş güvencesinin olmadığı bilinmektedir. Bu yazarın eserlerinde de açıkça gözükmektedir. Kötü şartlarda yaşayan ve ağır şartlar altında çalışan çocukların hasta olması kaçınılmazdır. Fakat eserlerde, çocukların hastalandıklarında bunu işverenlerine söylemedikleri görülmektedir. Muhtemelen böyle durumlarda işlerini kaybetme korkusu egemen olmaktadır. Daha önce de değinildiği gibi, çocuk çalışanların çoğunun maddi açıdan çalışmaya ihtiyacı vardır. Yine izinler de önceden sözlü olarak kararlaştırılmasına rağmen, oldukça esnek karakter göstermektedir. Bunun bir örneğini, yine "Dondurmacının Çırağı" öyküsündeki "Yarın izin gün, kızdım ya, dedi. On beş gün bir. Usta bırakmaz, iş var çok. Aldırma! Sen de yarından sonra gidersin. Ama köyden adam var görecek. Yarın var izin, dedi, gideceğim var bir kahve Galata. Var bizim köylü. Bakalım köyden ne haber" (Abasıyanık, 1952/2009g, s.101) kısımlarında görmek mümkündür. Gerek hastalık gerekse de izinle ilgili bu durumların ortaya çıkmasındaki

YIL: 5 SAYI: 10 
en büyük neden iş güvencesinin olmaması olarak görülebilir. Gerçekten işverenler bu çocukları istedikleri zaman işten çıarabilmekte ve yerlerine yeni çocuk işçiler bulabilmektedirler. "Dondurmacının Çırağı" öyküsündeki 'Usta izin vermeden çıktı gitti, dedi. İstanbul' da bir hafta onu aradım. Bulduğum zaman paltosunu bile satmıştı. "Paranı verdi mi usta, Todori?" dedim. 22 gün kesti dedi" (Abasıyanık, 1952/2009g, s.102) cümleleriyle aktarılan olay, iş güvencesi olmamasının sonuçlarını ortaya koyan bir örnek olarak karşımıza çıkmaktadır.

\section{4. İşsizlik ve İstihdam}

Bu konuda dikkat çeken nokta yazarın son dönemlerine denk gelen 1950 sonrasında işsizliğe değinmeye başlamış olmasıdır. Bunda çok partili dönem geçiş döneminde bir muhalefetin varlığlyla birlikte işçi hareketinin az da olsa hızlanması, sosyal ve ekonomik sorunların gündeme gelmeye başlaması ile yazarın bu dönemde hayata daha karamsar bakmaya başlaması ve dünyanın karanlık yönlerini daha çok masaya yatırmasının ilgisi, mutlaka ki vardır. Ayrıca öykülerinin arka planında artık ağırlıklı olarak şehir hayatının yer almasının da bu durumdaki etkisi yadsınamaz.

Eserlerde işsizlik konusunda asıl ayrım kır-kent ayrımı olarak göze çarpmaktadır. Öykülerde köylerde ve kasabalarda mutlaka herkesin bir işi varken; işsizlik, asıl olarak şehirde baş göstermektedir. Bu işsizlik durumu daha çok parasızlıktan değil de iş aramanın getirdiği bıkkınlık üzerinden ele alınır. Bu en açık Havada Bulut kitabının "Ay Işı̆̆ı" öyküsünde görülür. Öykünün kahramanı durumunu "Ben köyümden şehre indim. Yine iş aramaya koyuldum. Ah, bu iş aramak... Büyük şehirde bir iş aramak kadar korkunç hiçbir şey olamaz.” (s.23) diyerek tanımlamaktadır. Yine aynı kitapta "Büyük Hülyalar Kuralım" öyküsünde kahraman bu kez "Sanki ne olurdu? Bir iş bulamaz mıydı? 70-80 liralık bir şey... İşte, bu hayal, hakikat olamayacak kadar büyük bir hayal midir?" (s.37) diye sormaktaydı. Yazarın "Dört Zait" hikâyesinde ise frengi hastası bir işsizin sağlık muayenesinden geçtikten sonra kan tahlilini yorumlaması için yazara getirdiğinde ona hikayesini anlatırken söyledikleri dikkat çeker: "Işe gireceğim de şimdi. İyi bir iş buldum. Bilseniz ne kadar zamandır işsizim, beyağabey. 
Nihayet buldum. Nişanlıyım da. Her tarafım sağlam çıktı muayenede. En son bir de kan muayenesi yaptılar. Şartmış. Nasıl kanım da iyi mi dersin?" (Abasıyanık, 1950/2009d, s.29).

Yazar bir öyküsünde bir elektrikçi ile onun dülgerci olan babasının dönemsel işsizliklerine de değinmektedir. Alemdağ'da Var Bir Yllan kitabının "Panço'nun Rüyası" isimli bu hikâyesinde yine aynı evde oturan bu işçilerin gittikleri işlerde, eğer bir diğerine de iş çıkacaksa onları da yanlarına alarak birbirlerine destek verdiklerine de dikkat çekilmiştir (s28-31).

Yazarın iki öyküsünde de iş görüşmelerinde karşılaşılan haksızlıklar ve insan kayırmalarının örneklerine rastlarız. Havada Bulut kitabının "Ay Işı̆̆ı" öyküsünde iş arayan kahraman "Başmuharrir cenaplarının karşısına çıktım. Bana siyasi kanaatlerimi sordu." (s.24) diyerek dönemin siyasi ortamına da bir gönderme de bulunmaktadır. "Kumarbaz Hayri Efendi" öyküsünde ise öykünün kahramanı Hayri, insanların kendine önyargıyla bakmalarını "Bütün kabahati ayda 60 papele kapıcılık, uşaklık etmemesi, lise tahsili yaptı̆̆ halde bir bankaya girecek kadar futbol oynamamasıdır." (Abasıyanık, 1952/2009b, s.15) cümleleriyle açıklarken işe alımlarda konuyla ilgisiz olgularla da ilgilendiklerinin altını çizmektedir. Aynı zamanda insanların işsizler bakış açısını da eleştirmektedir.

Son olarak "Kumpanya" öyküsünde anlatılanlar göstermektedir ki eğitim görmüş kişiler bütün bu işsizlik sorununa rağmen özellikle devlet dairelerinde rahatlıkla alanlarından bağımsız iş bulabiliyorlardı (Abasıyanık, 1951/2006, s.67). Bu da dönemin Türkiye'sindeki eğitim seviyesinin düşüklüğüne (Konuk, 2012, s.328)w ve eğitimli istihdama duyulan ihtiyacı göstermektedir denilebilir.

\section{5. Örgütlenme ve Grev}

Sait Faik'in gerek öyküleri gerekse de romanları bu konuda çok kısır kalmışlardır. Elbette bu şaşılacak bir sonuç değildir. Yazıları 1936-1954 yılları arasında yayınlanan Sait Faik yaşadığı dönem gereği bu konulara değinememiştir. Bunun en önemli nedenleri yazarın son dönemlerine

YIL: 5 SAYI: 10 
kadar kendi yaşadığı ve tanık olduğu hikâyeleri konu edinmesi ve o dönemde Türkiye'de o dönemde gerek sınıf esasına göre cemiyet kurmayı yasaklayan kanunlar gerek dönem iktidarının sınıfları tanımamaya ilişkin sert tutumları, kentlerde sürekli üretim yapan bir sanayileşme olmamasıyla birleşerek yazarın canlı örnekle karşılaşmasını neredeyse olanaksız kılmış olması şeklinde açıklanabilir (Makal, 1999, s.447-448).

Fakat yine de yazarın 2 öyküsünde bu konulara atıf yapmış olduğunu görüyoruz. Bunlardan ilkine Semaver kitabının açılış öyküsü olan "Semaver" isimli hikâyenin sonuna doğru geçen "Yün eldivenler içinde saklı kıymettar elleri salep fincanını kucaklayan... kafaları grevli ameleler..." (s.12-13) cümlesinde rastlıyoruz. Elbette bu tanım her ne kadar o dönemde bu hak işçiler tanınmamış hatta işçiler bu hak için mücadele etmiyor gibi görünseler de yakın zamanda özellikle savaş sırasında yaşanmış tek tük grev örneklerinin bir yansıması olarak görülebilir.

Yine Semaver kitabının "Birtakım İnsanlar" isimli öyküsü, yazarın, örgütlenme hakları olmamasına rağmen öznel bir olay üzerine birlikte hareket eden işçilerle karşılaşması üzerine kurulmuştur. Otelde kalacak parası olmayan hamalların geceliği 5 kuruş karşıllı̆ında kaldıkları sabahçı kahvelerinden polis tarafından yasak gerekçesiyle çıkarılmaları üzerine hep birlikte gecenin bir yarısı valiyle konuşmak için konağa yürümeleri gerçekten dönemin hareketsizliği içerisinde aykırı bir örnek olarak gözükmektedir (s.69-70). Ayrıca öyküde yazarın arkadaşlarını arayan ve ona olayı anlatan işçinin kılığına kıyafetine bakıp "Valiye çıkmayı akıl edemezler. Bu muhakkak esrarkeştir.” (s.70) demesi üstünde durulmasi gereken bir olgudur. Gerçekten alt sınıf insanlara yakınlığıyla bilinen Sait Faik'in bile böyle düşünmesi işçi sınıfının o dönemki hareketsizliğinin insanlarda oluşturduğu ön yargının ve elitizmin bir yansımasıdır adeta. Öykünün sonunda, yazarın, tramvayın camından, valilik konağına yürüyen yaklaşık 80 hamalı gördüğü anı tanımlayışı oldukça etkileyicidir; bu an açıkça yazarı çok etkilemiştir. 
$310 \cdot$ YALOVA SOSYAL BILIMLER DERGISI

\section{Sonuç}

Öncelikle şunu belirtmek gerekir ki Sait Faik Abasıyanık'nn eserleri üzerinde yapılan bu incelemeler sonucunda, son dönemlerinde sürrealizme kaymış öykücülüğünün birkaç örneği dışarıda tutulmakla birlikte, gözlemlerini olduğu gibi aktaran bir yazar olarak Sait Faik'in eserleri, dönemin çalı̧̧ma ilişkilerinin irdelenmesi bakımından oldukça zengin bir kaynaktır. Yazar konuya dâhil olan pek çok alanda ayrıntılı gözlemlere dayanarak öyküler yazmıştır. Ayrıca yazarın ücretlilerle olan yakın ilişkisi, özellikle de dar gelirli insanlara duyduğu sevgi ve ilgi, eserlerinin genellikle bu tip insanlara yoğunlaşmasıyla sonuçlanmıştır. Yazarın yazı stilinin fiziksel gerçekliklerle birlikte, belki de daha çok insanların psikolojisine yönelmiş olması ve insanların duygu, düşünce ve hayallerini bizlere ayrıntılı biçimde bizlere aktarması; bu konunun psikolojik yanlarını da ayrıntılı bir şekilde incelememizi sağlamıştır. Gerçekten Sait Faik üzerinde çalışmanın en verimli yönünün bu olduğu söylenebilir. Son olarak şunu belirtmek gerekir ki yazar kendisi de gözlemleyecek firsat bulamadığ için tarım sektöründen hiç bahsetmemiştir. Öykülerindeki ücretliler ya adalarda çalışmaktadırlar ya da daha genel olarak kırdan şehre gelmiş ve şehirde çalışmaya başlamış kişilerdir.

Eserlerinde çalışma ilişkilerine sık sık yer veren Sait Faik, gerek ücretler ve yaşam standartları konusunda gerek çalışma koşulları konusunda kamuda ve özel sektörde çalışan ücretliler arasındaki ayrımı gözlemlemiş ve bize de eserlerinde bu ayrımı görebileceğimiz şekilde aktarmıştır. Yazar aralarındaki farklara dikkat çekmekle birlikte, bu iki farklı ücretli kesiminin birbirleriyle ve işverenlerle olan ilişkilerini de mercek altına almış; değişik anekdotlarla hikâyelerinde yer vermiştir. Bu ayrımda dikkat çeken bir durum da, yazarın işçilere oldukça yakın ve memurlara da bazı istisnaları olmak üzere daha soğuk baktı̆̆ını eserlerinde hissettirmesidir. Tüccarlardan ve işverenlerden hazzetmediğini ise öykülerinde açık açık belli etmiş ve hatta belirtmiştir. Yine de memur olmalarına rağmen öğretmenlerin yazarın gözünde ayrı bir yeri olduğu da açıkça göze çarpmaktadir.

YIL: 5 SAYI: 10 
Eserlerde işçilerin kendilerini hayatta tutacak kadar parayı bile zor kazandıkları görülmektedir. Bununla birlikte memurların nispeten daha rahat bir hayat sürdükleri gözlenmektedir. Elbette işçi mücadelesinin neredeyse hiç olmadığı ve kırdan kente göçün emekleme aşamasında olduğu bu dönemde işçilerin ücretlerini arttırmak için hiçbir güce sahip olmamalarının doğal yansıması olarak karşımıza çıkan ücretlerdir bunlar. Yine savaş döneminde aynı kalan ücretler ve firlayan fiyatların yaşattığı zorluklar da eserlerde kendisine yer bulmuştur. Aynı zamanda savaş bitmesine rağmen işçi ücretleri çok değişmemekle birlikte, memur ücretlerinin dikkat çekici yükselişi de eserlerin ilgi çeken ayrıntılarıdır.

Dönemde yürürlülükte olan 1936 tarihli İş Kanunu'nun yetersizlikleri ile işyeri güvenliği ve işçi sağlığı konusundaki sıkıntılar eserlere doğrudan yansımıştır. Takrir-i Sükûn Kanunu ve Cemiyetler Kanunu'nun engellediği işçi mücadelesi ve iş̧̧i örgütlenmelerinin eserlerde de bahsinin geçmemesi gayet doğaldır. Sait Faik bu konuda olması gerekenle değil olanla ilgilenen bir tutum almıştır. Fakat zaman zaman dayanamayıp işçilerin hareketsizliğine ve özellikle son dönemde kaynakların dağılımındaki adaletsizliğe isyan ettiği öyküleri de olmuştur.

Yazar çalışma saatlerine de öykülerinde değinmiş ve çok ayrıntıya girmese de kent çalışma hayatının zorluklarından ve insanlara kendilerine ayıracak zaman bırakmamasından sık sık bahsetmiştir. Fakat erken kalkma zorunluluğunun yazarın ilgisini uzun çalışma sürelerinden daha çok çektiği görülmektedir. Keza günde kaç saat çalışıldığıyla ilgili neredeyse hiçbir veriye rastlanılmamıştır.

Eserlerde ilginç olan bir başka ayrıntı, kadın çalışmasına dair neredeyse hiç bilginin bulunmamasıdır. Elbette bunun en büyük nedeni kadın çalışanların o dönemde genelde tarım sektöründe bulunması ve şehirlerde kadın işgücüne katılım oranının çok düşük olması olarak görülebilir. Bunun tersine, çocuk çalışmasına ilişkin çok fazla veri bulunmaktadır. O dönemde çocuk çalışan sayısında bir patlama olduğunu zaten kayitlar ve araştırmalar göstermektedir. Bu, Sait Faik'in eserlerinde de bol bol çocuk çalışanla karşılaşılmasına yol açmıştır. Çocukları çalışmaya başladıkları yaşlar, ücretler, çalışma saatleri, çalışma koşulları gibi bilgilere ulaşmak 


\section{$312 \cdot$ YALOVA SOSYAL BILIMLER DERGISI}

mümkündür. Eserlerden elde edilen bilgiler ışı̆̆ında denilebilir ki çocuklar aynı işi yapan yetişkinlere kıyasla daha uzun süre daha az ücretle çalıştırılmakta ve iş güvencesi ve sosyal güvenceden mahrum bir şekilde ağır işlere yöneltilmektedirler.

Son olarak toparlamak gerekirse Sait Faik, çok önemli bir gözlemci olarak ve gözlemlerini kaleme dökme konusundaki üstün yeteneğiyle döneme dair yapılacak çalışma ilişkileri araştırmalarında referans olamayacaksa bile iyi bir yardımcı kaynak olabilecek eserler vermiştir. Gerek fiziksel, gerek sayısal ve gerekse kendisi açısından en önemli farkı oluşturan psikolojik açıdan birçok veriye, yazarın eserlerinden ulaşmak mümkündür.

\section{Kaynakça}

Abasıyanık, S. F.(2008a), Alemdağ'da Var Bir Yllan, İstanbul: Yapı Kredi Yayınları(Illk baskı 1954)

Abasıyanık, S. F.(2008b), Birtakım İnsanlar, İstanbul: Yapı Kredi Yayınları(Ilk baskı 1944 Medar-l Maişet Motoru adıyla)

Abasıyanık, S. F.(2009a), Havada Bulut, İstanbul: Yapı Kredi Yayınları(Illk basım 1951) Abasıyanık, S. F.(2009b), Havuz Başı, İstanbul: Yapı Kredi Yayınları(Ilk basım 1952) Abasıyanık, S. F.(2008c), Kayı Araniyor, İstanbul: Yapı Kredi Yayınları(Illk basım 1953) Abasıyanık, S. F.(2006), Kumpanya, İstanbul: Yapı Kredi Yayınları(Illk basım 1951) Abasıyanık, S. F.(2009c), Lüzumsuz Adam, İstanbul: Yapı Kredi Yayınları(Illk basım 1948) Abasıyanı, S. F.(2009d), Mahalle Kahvesi, İstanbul: Yap1 Kredi Yayınları(İlk basım 1950) Abasıyanık, S. F.(2009e), Sarnıç, İstanbul: Yapı Kredi Yayınları(Illk basım 1939) Abasıyanık, S. F.(2009f), Semaver, İstanbul: Yapı Kredi Yayınları(İlk basım 1936) Abasıyanık, S. F.(2009g), Son Kuşlar, İstanbul: Yapı Kredi Yayınları(Illk basım 1952) Abasıyanık, S. F.(2008d), Şahmerdan, İstanbul: Yapı Kredi Yayınları(Illk basım 1940) Ağaoğlu, S. (1954), Sait Faik, Varlkk Dergisi, 409

YIL: 5 SAYI: 10 
Ediboğlu, B.S.(1954), Modern Türk Hikayesinin Kurucusu Sait Faik, Resimli Yirminci Asır Dergisi, 92

Howard, D.A.(2001), The History of Turkey, Westport CT: Greenword Publishing Group

Konuk, O. (2012), Bir Sorun ve Çözüm Kaynağı Olarak Türk Eğitim Sistemi, Mehmet Zencirkıran(Ed.), Dünden Bugüne Türkiye'nin Toplumsal Yapısı içinde s.375-386, Bursa: DORA

Makal, A.(1999), Türkiye'de Tek Partili Dönemde Çalışma Illişkileri: 1920-1946, Ankara: İmge Kitabevi

Sait Faik Abasıyanık(1993-1994), Théma Larousse: Tematik Ansiklopedi içinde (Cilt: 6 s. 96) Tataroğlu, M.(2012), Cumhuriyetten Günümüze Türk Bürokrasisi, Memet Zencirkıran(Ed.),

Dünden Bugüne Türkiye’nin Toplumsal Yapısı içinde s.221-245, Bursa: DORA Yücel, T. (1954), Sait Faik, Varlık Dergisi, 413 